\title{
ÇOCUĞUN KİŞiLIĞİNiN ANA BABAYA KARŞI KORUNMASI
}

\author{
Dr. S. Hülya IMAMO $\breve{G} L U^{*}$
}

\section{Giriș}

$\mathrm{Bu}$ çalışmada velayet altında bulunan çocuğun kişiliğinin ana babaya karşı korunması konusu ele alınmıştır. Konu, 4721 sayılı Yeni Türk Medeni Kanunu'nun çocuğun korunmasına yönelik önlemleri öngören 346 vd. hükümleri ile kişiliğin korunmasına yönelik genel nitelikli düzenlemeleri oluşturan 24 ve 25 . maddeleri çerçevesinde ${ }^{1}$ incelenmiştir. Bu çerçevede özellikle 4721 sayılı Türk Medeni Kanunu'nun çocuğun korunmasına yönelik önlemler bakımından getirdiği bazı değişikliklerle birlikte, çocuğun kişiliğinin ana babanın hukuka aykırı müdahalesi sonucu ihlal edilmesinin şartları ve Kanun'un 24 ve 25. maddelerinin ana baba ve çocuk arasındaki ilişkiye uygulanabilirliği üzerinde durulmuştur. Ancak daha önce gerçek kişilere ilişkin olarak kişilik hakkı kavramı ve kişiliğin korunması hususunda genel bilgilerin verilmesi gerekli görülmüştür.

\section{Genel Olarak Kişilik Hakkı Kavramı ve Kişilik Hakkının Korunması}

\section{Kișilik Hakkı Kavramı}

Kişilik, doğal anlamıyla, kişi olarak insanı ifade eder; diğer bir deyişle bu anlamda kişilik, düşünen varlık olarak ve bireyselliğiyle insandır². Kişi ve

\footnotetext{
* Ankara Üniversitesi Hukuk Fakültesi Medeni Hukuk Anabilim Dalı

${ }^{1}$ Bu çalışmada 4320 sayılı Ailenin Korunmasına Dair Kanun (RG.17.01.1998, S.23233)'un hükümleri üzerinde durulmayacaktır. Bununla birlikte bkz., dn.91.

${ }^{2}$ Peter Jäggi, "Fragen des privatrechtlichen Schutzes der Persönlichkeit", ZSR, Neue Folge,
} 
kişilik, insanı kendine özgü yetenekleriyle ve bu yeteneklerin oluşumu ve gelişimiyle birlikte kavramaktadır ${ }^{3}$.

Hukuki anlamda kişilik kavramı, kişinin sahip bulunduğu temel bireysel değerlerinin bütünü olarak anlaşılmaktadır ${ }^{5}$. Bu temel bireysel değerlerin bütünü üzerindeki hak ise kișilik hakkıdır ${ }^{6}$. Bu noktada genel bir kişilik hakkından söz etmek mümkündür ${ }^{7}$. Doktrinde TMK 24 anlamında genel kişilik hakkının hukuki içeriğinin, gerçekte ancak insanlık onuruna sayg1 gösterilmesine ilişkin etik gerekten hareketle doğru biçimde anlaşılabileceği ifade edilmiştir ${ }^{8}$; kişi, kişilik hakkıyla bölünemez ve dokunulamaz bir varlık olarak onuru ve özgürlüğüyle hukuk düzenine dahil

Band 79, 1960, Heft 4, s.145a-146a.

3 Andreas Meili, Basler Kommentar zum Schweizerischen Privatrecht (Hrsg., Heinrich Honsell/Nedim Peter Vogt/Thomas Geiser), Zivilgesetzbuch I, Art.1-456, 2. Auflage, Basel 2002, Art.28 N 5.

${ }^{4}$ Tüzel kişiler, doğal anlamda kişi değildir (Jäggi, s.158a). Tüzel kişiler, belirli niteliklere sahip kişi ya da mal topluluklarıdır. Söz konusu kişi ya da mal toplulukları, hukuk düzeni tarafından toplum hayatının doğurduğu çeşitli ihtiyaçları karşılamak amacıyla kişi olarak kabul edilmiştir (Bu hususta bkz., Mustafa Dural/Tufan Öğüz, Türk Özel Hukuku, Cilt II, Kişiler Hukuku, 7. Bası, İstanbul 2004, s.5, 7vd.).

5 Heinz Hausheer/Regina E. Aebi-Müller, Das Personenrecht des Schweizerischen Zivilgesetzbuch, Bern 1999, Rz 10.02; Andreas Bucher, Natürliche Personen und Persönlichkeitsschutz, 2. Auflage, Basel-Frankfurt a.M. 1995, N 457; Richard Frank, Persönlichkeitsschutz heute, Zürich 1983, N 82-83, N 105. Pozitif hukuk, kişilik kavramını, ayrıca hak ehliyeti anlamında kullanmıştır (Bu hususta bkz., Mario M. Pedrazzini/Niklaus Oberholzer, Grundriss des Personenrechts, 3. Auflage, Bern 1989, s.112; Jäggi, s.148a vd.; ayrıca Hausheer/Aebi-Müller, Rz 10.01). Jäggi'ye göre, hukuk mantığı açısından kişilik kavramı, hak süjeliğini, yani hakların ve yükümlülüklerin bağlantı noktası olarak kişiyi ifade eder (s.147a vd.).

${ }^{6}$ Krş., Jäggi, s.167a; Aydın Zevkliler/M. Beşir Acabey/K. Emre Gökyayla, Medeni Hukuk, Giriş-Başlangıç Hükümleri-Kişiler Hukuku-Aile Hukuku, 6. Baskı, Ankara 2000, s.395. Kişilik hakkına ilişkin olarak Türk hukukunda ayrıca bkz., Dural/Öğüz, s.92vd.; M. Kemal Oğuzman/Özer Seliçi/Saibe Oktay, Kişiler Hukuku (Gerçek ve Tüzel Kişiler), 7. Bası, İstanbul 2002, s.116vd.; Ergun Özsunay, Gerçek Kişilerin Hukuki Durumu, 4. Bası, İstanbul 1979, s.148vd.; Bilge Öztan, Şahsın Hukuku, Hakiki Şahıslar, 10. Bası, Ankara 2001, s.111vd.; Haluk Tandoğan, "Şahsiyetin Akit Dışı İhlallere Karşı Korunmasının İşleyiş Tarzı ve Basın Yoluyla Olan İhlallere Karşı Özel Hayatın Korunması", Ankara Üniversitesi Hukuk Fakültesi Dergisi, Cilt XX (1963), Sayı 1-4, s.12vd.

${ }^{7} \mathrm{Bu}$ hususta bkz., Dural/Öğ̈̈z, s.92-93; Zevkliler/Acabey/Gökyayla, s.396vd; Tandoğan, s.12; Kemal Oğuzman, "İsviçre ve Türkiye'de Medeni Kanun ve Borçlar Kanununda Şahsiyetin Hukuka Aykırı Tecavüze Karşı Korunması ve Özellikle Manevi Tazminat Davası Bakımından Yapılan Değişiklikler”, Prof. Dr. Haluk Tandoğan'ın Hatırasına Armağan, Ankara 1990, s.9-10. Bucher, kişilik kavramının içeriğini teşkil eden temel bireysel değerlerin oldukça farklı mahiyette olması sebebiyle, hepsini kapsayan bir kişilik hakkından bahsetmenin yaygın olmadığını belirtmektedir; bilakis her kişilik değerinin, onun korunmasını içeren bir kişilik hakkıyla tamamlanması mutattır, mesela vücut bütünlüğünün korunması hakk1 veya onurun korunması hakkı gibi ( N 458); ayrıca bkz., Jäggi, s.169a.

${ }^{8}$ Krş., Frank, N 81'de atıf yapılan Jörg Paul Müller, Die Grundrechte der Verfassung und der Persönlichkeitsschutz des Privatrechts, Diss., Bern 1964, s.46-47. 
olmaktadır. Aynı şekilde kişiliğin özü nasıl ki kesin sınırlar içine alınamazsa, genel kişilik hakkı da içeriği bakımından nihai olarak belirlenemez'. Gerçekten de kişilik hakkının bağlantı noktasını teşkil eden kişilik kavramının içeriğini oluşturan temel bireysel değerlerin nihai ve eksiksiz olarak belirlenmesi mümkün değildir ${ }^{10}$; zira bu temel değerler, tarihi süreçte toplumdaki görüş ve tasavvurların değişimine ve özellikle bilim ve teknikteki ilerlemelere bağlı bir gelişim seyri göstermektedir ${ }^{11}$. Buna göre, mesela tıp ve iletişim alanında olduğu gibi yeni değer kategorilerinin teşekkülü mümkündür ${ }^{12}$.

Kişinin temel bireysel değerleri, genel olarak fiziksel, duygusal ve sosyal kişilik değerleri biçiminde bir ayrıma tabi tutulabilirr ${ }^{13}$. Burada nihai bir tespit söz konusu olmaksızın, başlıca fiziksel kişilik değerleri olarak hayat, vücut bütünlüğü (bedensel ve ruhsal sağlık), kişisel özgürlük, özellikle kişinin hareket özgürlüğü ve cinsel özgürlük anılabilir; kişinin duygu hayatı, özellikle ailesi ve diğer yakınları ile ilişkileri, duygusal kişilik değerleri arasında yer alırken, adı, resmi, sesi, onuru, özel ve gizli alanı, ekonomik özgürlüğü ise sosyal kişilik değerlerini oluşturur ${ }^{14}$.

Kişilik hakkı, kişilik değerleri üzerinde prensipte başkasının etkisi olmaksızın hükmetme yetkisini içerir ${ }^{15}$. Kişilik hakk1, esasen savunmaya yarayan bir haktır ${ }^{16}$. Şöyle ki; kişilik hakk1, kişiyi üçüncü kişilerce gerçekleştirilen ihlallerden korumayı amaçlar, buna karşılık üçüncü kişiler karşısında olumlu taleplere vücut vermez ${ }^{17}$. Bu bağlamda mesela, kişilik hakkına dayanarak üçüncü kişiden, hukuk düzeninin onu yükümlü kılmadığı bir davranışta bulunması istenemez.

Kişilik hakkı, kişinin kişi olması sebebiyle sahip bulunduğu ve kişiliğine ayrılmaz biçimde bağlı haktır ${ }^{18}$. Bu sebeple kişilik hakkı, ilke olarak devredilemez, mirasçılara geçmez, kişinin ölümüyle son bulur ${ }^{19}$. Buna

\footnotetext{
${ }^{9}$ Müller (Bkz., dn.8), s.46-47; ayrıca BSK ZGB I-Meili, Art.28 N 5.

${ }^{10}$ Krş., Pedrazzini/Oberholzer, s.113vd., 132vd.; Bucher, N 462; Dural/Öğüz, s.92-93; Öztan, Şahsın Hukuku, s.117-118; Zevkliler/Acabey/Gökyayla, s.398, 401.

${ }_{11}^{11}$ Pedrazzini/Oberholzer, s.113, 133; Bucher, N 463; Frank, N 83; Dural/Öğüz, s.93; Öztan, Şahsın Hukuku, s.118; Zevkliler/Acabey/Gökyayla, s.398, 401.

${ }_{12}$ Bucher, N 463.

${ }^{13}$ Bucher, N 465vd.; ayrıca BSK ZGB I-Meili, Art.28 N 16-17; Hasan İşgüzar, "3444 Sayılı Kanunla Değiştirilen Borçlar Kanununun 49. Maddesine Göre Kișilik Hakkının İhlali Nedeniyle Manevi Tazminat Davasının Şartları”, Ankara Barosu Dergisi, 1990, Sayı 6, s.857.

${ }^{14}$ Krş., Bucher, N 466vd., N 470vd., N 476vd.; BSK ZGB I-Meili, Art.28 N 17; İşüguzar, s. $857,858 \mathrm{vd}$.

15 Jäggi, s.167a; Zevkliler/Acabey/Gökyayla, s.396; Tandoğan, s. 12.

${ }^{16}$ Bucher, N 459; Hausheer/Aebi-Müller, Rz 10.11, Rz 12.08; Oğuzman/Seliçi/Oktay, s.118.

17 Bucher, N 459; Hausheer/Aebi-Müller, Rz 10.11-10.12, Rz 12.08; ayrıca krş., Pedrazzini/Oberholzer, s.132.

${ }^{18}$ Hausheer/Aebi-Müller, Rz 10.02; Bucher, N 457, N 508; Pedrazzini/Oberholzer, s.174vd.; Öztan, Şahsın Hukuku, s.116.

${ }^{19}$ BSK ZGB I-Meili, Art.28 N 7; Pedrazzini/Oberholzer, s.174-175; Hausheer/Aebi-Müller,
} 
karşılık kişiliğin ihlalinden doğan malvarlığına ilişkin talepler, ilke olarak devredilebilir ve miras yoluyla geçer ${ }^{20}$. Manevi tazminat talebi ise, TMK 25/IV hükmüne göre karşı tarafça kabul edilmiş olmadıkça devredilemez ve mirasbırakan tarafindan ileri sürülmüş olmadıkça mirasçılara geçmez ${ }^{21}$.

Mutlak bir hak olarak kişilik hakkı, herkese karşı ileri sürülebilir ve herkes, kişilik hakkına riayet etmek zorundadır ${ }^{22}$. Öte yandan kişilik hakkı, kişiye sıkı sıkıya bağlı hak niteliğindedir; bu bağlamda kişilik hakk1, ayırt etme gücüne sahip küçük veya kısıtlı tarafindan kanuni temsilcinin katılımı olmaksızın kullanılabilit² ${ }^{23}$.

\section{Kişilik Hakkının Korunması}

Özel hukukta kişiliğin korunmasına ilişkin temel hükümler, Türk Medeni Kanunu'nun 23, 24 ve 25. maddelerinde yer almaktadır ${ }^{24}{ }^{25}$. Bu

Rz 10.23, Rz 10.25; Bucher, N 506vd., N 508, N 510; krş., Öztan, Şahsın Hukuku, s.116-117; Oğuzman/Seliçi/Oktay, s.117.

${ }^{20}$ Pedrazzini/Oberholzer, s.175; Hausheer/Aebi-Müller, Rz 10.23, Rz 10.25; Bucher, N 508, N 510; BSK ZGB I-Meili, Art.28 N 7.

${ }^{21} 4721$ sayılı Yeni Medeni Kanun'dan önce eski Medeni Kanun'a 3444 sayılı Kanunla eklenen 24a maddesi, manevi tazminat talebinin karşı tarafça kabul edilmedikçe devredilemeyeceği, ancak miras yoluyla intikal edeceği hükmünü öngörüyordu. $\mathrm{Bu}$ düzenleme, manevi tazminat talebinin mirasçılara geçmesi için mirasbırakan tarafından ileri sürülmüş olmasını aramaması sebebiyle doktrinde tartıșmalara yol açmıștı. Bu hususta bkz., Dural/Öğüz, s.151-152; tartışma ve görüşler için Oğuzman, s.45, dn.124; Selahattin Sulhi Tekinay, "Kişilik Haklarına İlişkin Yasal Değişiklikler Hakkında Eleştiriler", Prof. Dr. Haluk Tandoğan'ın Hatırasına Armağan, Ankara 1990, s.61; Rona Serozan, "Manevi Tazminat İstemine Değişik Bir Yaklaşım”, Prof. Dr. Haluk Tandoğan'ın Hatırasına Armağan, Ankara 1990, s.93vd.; ayrıca Fikret Eren, Borçlar Hukuku, Genel Hükümler, 8. Bası, İstanbul 2003, s.752vd. İsviçre hukukunda farklı görüşlerle birlikte manevi tazminat talebinin, hak sahibinin bu talebi ileri sürme hususundaki iradesini ortaya koyması halinde devredilebileceği ve mirasçılara geçebileceği kabul edilmektedir. Öte yandan bir görüşe göre, bu sınırlamadan da vazgeçilmelidir; bu görüş uyarınca manevi tazminat talebi, genel olarak devredilebilir ve hak sahibi, manevi tazminat talebini ileri sürme hususundaki iradesini ölümünden önce açıklamış olmasa da mirasçılara geçebilir. Bu konuda bkz. ve krş., Eugen Bucher, Berner Kommentar zum schweizerischen Privatrecht, Band I, Einleitung und Personenrecht, 2. Abteilung, Die natürlichen Personen, Erster Teilband, Kommentar zu den Art.11-26 ZGB, Bern 1976, Art.19 N 233; Karl Oftinger, Schweizerisches Haftpflichtrecht, Erster Band, Allgemeiner Teil, Zürich 1975, s.293; Heinrich Honsell, Schweizerisches Haftpflichtrecht, 2. Auflage, Zürich 1996, § 10 N 5; Heinz Rey, Ausservertragliches Haftpflichtrecht, 2. Auflage, Zürich 1998, N 446; Ingeborg Schwenzer, Schweizeriches Obligationenrecht, Allgemeiner Teil, Bern 1998, N 90.25; Pedrazzini/Oberholzer, s.175; Hausheer/Aebi-Müller, Rz 10.23, Rz 10.25.

${ }_{22}$ Hausheer/Aebi-Müller, Rz 10.20; Bucher, N 505; Öztan，Şahsin Hukuku， s.117; Oğuzman/Seliçi/Oktay, s.117; Dural/Öğüz, s.95.

${ }^{23}$ Bucher, N 512; Hausheer/Aebi-Müller, Rz 10.19; BSK ZGB I-Meili, Art.28 N 9.

24 Dural/Öğüz, s.134; Oğuzman/Seliçi/Oktay, s.129; Zevkliler/Acabey/Gökyayla， s.427; Öztan, Şahsın Hukuku, s.141; ayrıca bkz. ve krş., Hausheer/Aebi-Müller, Rz 10.08; Hans Michael Riemer, Personenrecht des ZGB, Studienbuch und Bundesgerichtspraxis, 2. Auflage, 
hükümler, doğrudan kişiliği korumaktadır ${ }^{26}$.

TMK 23 hükmü, irade özerkliğini, özellikle sözleşme özgürlügünü sınırlamak suretiyle kişiliğin hukuki işlem sonucu ihlalini önlemeye yönelmiştir ${ }^{27}$. Buna göre kişi, hukuki işlem yoluyla hak ve fiil ehliyetinden kısmen de olsa vazgeçemez (TMK 23/I); doktrinde burada kișinin gelecekte taahhüt ve tasarruf işlemi yapma imkanının korunduğu ifade edilmektedir ${ }^{28}$. Aynı biçimde kişi, özgürlüklerinden de hukuki işlem yoluyla vazgeçemez veya onları hukuka ya da ahlaka aykırı olarak sinırlayamaz (TMK 23/II). Burada ise kişinin geleceğine ilişkin olarak karar verme serbestisinin korunması ve güvence altına alınması amaçlanmaktadır ${ }^{29}$. TMK 23 hükmü ile sözleşme özgürlüğünün sınırlanması suretiyle kişiliğin normatif düzeyde korunduğu söylenebilir ${ }^{30}$.

TMK 24 hükmü ise, kişiliği hukuki işlem dışında kalan ihlallere karşı korumaktadır $^{31}$; anılan hükmün ilk fıkrasına göre kișinin kişilik hakkına üçüncü kișiler tarafından hukuka aykırı olarak saldırılması halinde, hakimden saldırıda bulunanlara karşı koruma istenebilir. Bu suretle TMK 24 hükmü, başkasının kişilik alanına hukuka aykırı olarak müdahalede bulunulmasını yasaklayan bir içerik taşımaktadır ${ }^{32}$. TMK 24 hükmü ile kişiliğin fiili düzeyde korunduğunu söylemek mümkündür ${ }^{33}$.

Bern 2002, N 291, N 295; Pedrazzini/Oberholzer, s.112.

${ }^{25}$ TMK 23, 24 ve 25, kişiliği koruyucu genel nitelikli hükümlerdir. Borçlar Kanunu'nun kişilik hakkının ihlali halinde manevi tazminatı düzenleyen 49. maddesi hükmü de genel nitelikli bir hüküm olarak kişiliği koruyucu hükümler çerçevesinde değerlendirilmektedir. Öte yandan anılan genel hükümlerin dışında münferit kişilik değerlerini korumaya yönelmiş özel nitelikli hükümler de mevcuttur, mesela adın korunmasını düzenleyen TMK 26 veya adam öldürülmesi ve vücut bütünlüğünün ihlalinden doğan manevi zararların tazminini düzenleyen BK 47 gibi. Bu konuda bkz., Dural/Öğüz, s.134; Zevkliler/Acabey/Gökyayla, s.427; Öztan, Şahsın Hukuku, s.114; ayrıca bkz. ve krş., Hausheer/Aebi-Müller, Rz 10.08, Rz 10.66vd.; Riemer, N 295.

${ }^{26}$ Zevkliler/Acabey/Gökyayla, s.428; krş., Hausheer/Aebi-Müller, Rz 10.09.

27 Krș., Dural/Öğüz, s.135vd.; Zevkliler/Acabey/Gökyayla, s.431vd., 435; Öztan, Sahsın Hukuku, s.141vd.; Pedrazzini/Oberholzer, s.120vd.; Eugen Bucher, Berner Kommentar zum schweizerischen Privatrecht, Band I, Einleitung und Personenrecht, 2. Abteilung, Die natürlichen Personen, Zweiter Teilband, Kommentar zu Art.27 ZGB, Bern 1993, Art.27 N 1; Claire Huguenin, Basler Kommentar zum Schweizerischen Privatrecht (Hrsg., Heinrich Honsell/Nedim Peter Vogt/Thomas Geiser), Zivilgesetzbuch I, Art.1-456, 2. Auflage, Basel 2002, Art.27 N 1.

${ }^{28}$ Krş., BK-Bucher, Art.27 N 41-42; Hausheer/Aebi-Müller, Rz 11.03, Rz 11.04.

29 Krş., Hausheer/Aebi-Müller, Rz 11.06vd., Rz 11.08, Rz 11.09; Bucher, $\mathrm{N}$ 429; Pedrazzini/Oberholzer, s.122vd.; Dural/Öğüz, s.137-138; Öztan, Şahsın Hukuku, s.143.

${ }^{30} \mathrm{Krş.,} \mathrm{Hausheer/Aebi-Müller,} \mathrm{Rz} 10.60$.

${ }^{31}$ Dural/Öğüz, s.138vd.; Öztan, Şahsın Hukuku, s.146; Zevkliler/Acabey/Gökyayla, s.458vd.; krş., Hausheer/Aebi-Müller, Rz 10.61, Rz 12.01vd.; Riemer, N 335, N 303.

${ }^{32}$ Krș., Hausheer/Aebi-Müller, Rz 12.02.

${ }^{33} \mathrm{Krş.,} \mathrm{Hausheer/Aebi-Müller,} \mathrm{Rz} 10.61$. 
TMK 24 hükmünde kişilik hakkı tanımlanmadığı gibi kişilik hakkına saldırı veya kişilik hakkının zedelenmesi (ihlali) olgusu da tanımlanmamıştır ${ }^{34}$. Böylece değişen koşullara bağlı olarak bir yandan yeni kişilik değerlerinin dikkate alınması, diğer yandan da henüz öngörülemeyen müdahale olgularının hükmün kapsamına dahil edilmesi mümkün kılınmıştır. Bu yönüyle TMK 24, münferit halde somutlaştırılması gereken genel bir hüküm niteliğindedir ${ }^{35}$.

Kişilik hakkına yönelik bir müdahalenin saldırı sayılabilmesi için, müdahalenin hukuka aykırı olması gerekiir ${ }^{36}$. Kişilik hakkının mutlak karakteri dolayısıyla kişilik hakkına yönelik her müdahale, ilke olarak hukuka aykırıdır ${ }^{37}$. Ancak hukuka uygunluk sebeplerinin bulunması halinde, müdahalenin hukuka aykırılığından söz edilemez ${ }^{38}$. TMK 24/II hükmü çerçevesinde hukuka uygunluk sebepleri olarak kişilik hakk1 zedelenen kişinin rızas1, daha üstün nitelikte özel veya kamusal yarar ya da kanunun verdiği yetkinin kullanılması hallerine işaret edilmiștir ${ }^{39}$.

Kişilik hakkına saldırıya karşı açılabilecek davalar, TMK 25 hükmünde yer almaktadır; burada kişiliği koruyucu savunma ve tazminat talepleri düzenlenmiştir ${ }^{40}$. Buna göre savunma talepleri bağlamında önleme, durdurma ve saldırının hukuka aykırılığının tespiti davaları açılabilir ${ }^{41}$. Önleme davası, saldırının henüz meydana gelmediği, fakat saldırı tehlikesinin bulunduğu hallerde açı1ır ${ }^{42}$; bu dava ile bazı belirtilerle ilerde meydana gelmesi mümkün görünen bir saldırının gerçekleşmesinin engellenmesi amaçlanır. Durdurma davası, başlamış ve devam etmekte olan

\footnotetext{
${ }^{34}$ Krş., Hausheer/Aebi-Müller, Rz 10.14; Riemer, N 337; BSK ZGB I-Meili, Art.28 N 38; ayrıca Pedrazzini/Oberholzer, s.129vd.

${ }^{35}$ Krş., Hausheer/Aebi-Müller, Rz 10.14; ayrıca Riemer, N 337.

${ }^{36} \mathrm{Krş.,} \mathrm{Dural/Öğ̈̈z,} \mathrm{s.138.}$

${ }^{37}$ Bucher, N 515; BSK ZGB I-Meili, Art.28 N 45; Pedrazzini/Oberholzer, s.129vd.; Riemer, N 368; Oğuzman, s.10; krş., Dural/Öğ̈̈z, s.138.

${ }^{38}$ Bucher, N 516; BSK ZGB I-Meili, Art.28 N 46; Pedrazzini/Oberholzer, s.129-130, 143vd.; Riemer, N 368-369; Hausheer/Aebi-Müller, Rz 12.14vd.; Dural/Öğüz, s.138-139; Oğuzman, s.10vd.

${ }^{39}$ Hukuka uygunluk sebeplerine ilişkin olarak ayrıntılı bilgi için bkz., Dural/Öğüz, s.139vd.; ayrica Bucher, N 517vd.; BSK ZGB I-Meili, Art.28 N 47vd.; Riemer, N 371vd.; Pedrazzini/Oberholzer, s.143vd.; Hausheer/Aebi-Müller, Rz 12.17vd.

${ }^{40}$ Eren, s.747; Öztan, Şahsın Hukuku, s.151, 152vd.; bu hususta bkz. ve krş., Hausheer/AebiMüller, Rz 14.14, Rz 14.15vd.; BSK ZGB I-Meili, Art.28a N 1vd. ; Bucher, N 570vd.; kişiliği koruyucu davalara ilişkin olarak Türk hukukunda ayrıca bkz. ve krş., Serap Helvacı, Türk ve İsviçre Hukuklarında Kişilik Hakkını Koruyucu Davalar (MK md.24/a fikra I/ İMK md.28a fikra I), İstanbul 2001, s.79vd., 86vd., 128vd.

${ }^{41}$ Eren, s.747; Öztan, Şahsın Hukuku, s.151; krş., BSK ZGB I-Meili, Art.28a N 2vd.; Hausheer/Aebi-Müller, Rz 14.15.

42 Dural/Öğüz, s.142vd.; Eren, s.747; Oğuzman/Seliçi/Oktay, s.150vd.; Öztan, Şahsın Hukuku, s.153vd.; ayrica Hausheer/Aebi-Müller, Rz 14.16vd.; Riemer, N 389; Bucher, N 571vd.; BSK ZGB I-Meili, Art.28a N 2; Pedrazzini/Oberholzer, s.153.
} 
saldırıya son verilmesi amacıyla açılır ${ }^{43}$; saldırı sona ermiş ise, bu dava açılamaz. Saldırının hukuka aykırılığının tespiti davası ise, saldırının sona ermesine rağmen etkilerinin devam etmesi halinde aç1lır ${ }^{44}$; bu suretle kişilik hakkına saldırının hukuka aykırılığının tespiti yönüne gidilir. Öte yandan TMK 25/II hükmü çerçevesinde önleme, durdurma veya saldırının hukuka aykırılığının tespiti ile birlikte, düzeltmenin veya hakimin kararının üçüncü kişilere bildirilmesi ya da yayımlanması talebinde de bulunulabilir ${ }^{45}$.

Kişilik hakkı saldırıya uğrayanın maddi ve manevi tazminat taleplerine TMK 25/III hükmünde işaret edilmiştir. Tazminat davaları ile kişilik hakkına yapılan hukuka aykırı saldırıdan doğan maddi veya manevi zararın giderilmesi amaçlanır. Burada tazminata hükmedilebilmesi için saldırıda bulunan kişinin kusurlu olması gerekir (BK 41vd.); ancak kusursuz sorumluluk hallerinde kusur şartı aranmaz ${ }^{46}$.

TMK 25 uyarınca kişilik hakkına saldırı dolayısıyla saldırıda bulunan kişi tarafından elde edilmiş olan kazancın iadesi de istenebilir. Bu bağlamda kişilik hakkı saldırıya uğrayan, söz konusu kazancın kendisine verilmesini gerçek olmayan vekaletsiz iş görme hükümlerine göre talep edebilir ${ }^{47}$. Burada saldırıda bulunan kişinin kusurlu olması şart değildir.

\section{III. Çocuk Kavramı ve Çocuğun Kişilik Hakkı}

Çocukluk, doğumla başlarr ${ }^{48}$; buna karşıllık çocukluğun sonu, konuşma dilindeki anlamına veya uzmanlık dalına göre farklı bir yaş basamağına isabet eder ${ }^{49}$. Çocuk deyiminin sadece bir soy ilişkisini ifade etmek için kullanılması halinde ise, çocukluk ancak ölümle son bulur ${ }^{50}$.

\footnotetext{
${ }^{43}$ Dural/Öğüz, s.142; Eren, s.747; Oğuzman/Seliçi/Oktay, s.147vd.; Öztan, Şahsın Hukuku, s.152vd.; ayrica Hausheer/Aebi-Müller, Rz 14.24vd.; Riemer, N 385vd.; Bucher, N 574vd.; BSK ZGB I-Meili, Art.28a N 4; Pedrazzini/Oberholzer, s.154.

${ }^{44}$ Dural/Öğüz, s.144; Eren, s.747; ayrıca Riemer, N 390; Bucher, N 579vd.; Hausheer/AebiMüller, Rz 14.30vd.; BSK ZGB I-Meili, Art.28a N 6vd.; Pedrazzini/Oberholzer, s.154vd.

${ }^{45}$ Bu hususta bkz. ve krş., Dural/Öğüz, s.144vd.; ayrıca Riemer, N 391vd.; Bucher, N 582vd.; Hausheer/Aebi-Müller, Rz 14.45vd.; BSK ZGB I-Meili, Art.28a N 9vd.; Pedrazzini/Oberholzer, s.156vd.

${ }^{46}$ Dural/Öğüz, s.146vd.; Oğuzman, s.27, 36; Oğuzman/Seliçi/Oktay, s.155, 159; Eren, s.748; İşgüzar, s.871-872; Ahmet Kılıçoğlu, "Medeni Kanunda Manevi Tazminatta Ağır Kusur Konusunda Yapılan Değişiklik”, Prof. Dr. Haluk Tandoğan'ın Hatırasına Armağan, Ankara 1990, s.107vd.; ayrıca bkz. ve krş., Hausheer/Aebi-Müller, Rz 14.54vd., Rz 14.70vd., Rz 14.76; Bucher, N 600vd., N 602vd.

${ }^{47} \mathrm{Bu}$ hususta Dural/Öğ̈̈z, s.145vd.; Eren, s.748; ayrıca Bucher, N 605; Riemer, N 411; Hausheer/Aebi-Müller, Rz 14.78vd.; BSK ZGB I-Meili, Art.28a N 18-19.

${ }^{48}$ Rona Serozan, Çocuk Hukuku, İstanbul 2000, N 10; Ali Naim İnan, Çocuk Hukuku, İstanbul 1968, s.11; Andreas Brauchli, Das Kindeswohl als Maxime des Rechts, Zürich 1982, s.25.

${ }^{49}$ Brauchli, s.25.

${ }^{50}$ Brauchli, s.25.
} 
Gelişim psikolojisinde sıkça çocuktan söz edilse de genel olarak kavramın yeknesak kullanımı yoktur; zira insanın gelişimi, mevcut genetik, sosyo-kültürel ve ruhsal faktörlere bağlı olarak bireysel gerçekleştiği için psikolojik açıdan çocuk kavramının kesin yaş sınırlarılyla belirlenmesi, neredeyse imkansız ve her şeyden önce pratikte faydasızdır ${ }^{51}$. Psikologlar, doğumdan ergenlik öncesine kadar olan safhayı, bebeklik, küçük çocukluk ve sonraki çocukluk gibi münferit dönemlere ayırmaktadır ve ergenlik öncesine adım atmakla çocukluğun sona ermesinden söz etmektedir ${ }^{52}$. Tıbbi açıdan da çocuk kavramı, büyük ölçüde psikolojik anlamdaki çocuk kavramı ile özdeştir ${ }^{53}$.

Öte yandan günlük dilde de çocuk kavramı, farklı anlamlarda kullanılır ${ }^{54}$. Genel olarak günlük dilde çocukluk, psikolojik veya tıbbi çocukluktan daha uzun süre devam eder ve çocukluktan yetişkinliğe geçiş oldukça bireysel değerlendirilir ${ }^{55}$.

Hukuki açıdan çocuk kavramı, bir yandan yaş ölçütüne göre çocukluğu yetişkinlikten ayırmak maksadıyla kullanılır ${ }^{56}$; bu bağlamda Türk hukuku açısından kanuni erginlik yaşı olan onsekiz yaşın doldurulmasıyla çocukluk sona erer $(\mathrm{TMK} 11 / \mathrm{I})^{57}$. Diğer yandan hukuken çocuk kavramı, insanın ana babasıyla arasındaki soybağını ifade etmek için de kullanılır ${ }^{58}$. Burada çocuk kavramı, yaştan bağımsızdır ${ }^{59}$.

Kişiliğin başlangıcı, Türk Medeni Kanunu'nun 28. maddesi hükmüyle belirlenmiştir. Buna göre kişilik, çocuğun sağ olarak tamamıyla doğduğu anda başlar. Böylece çocuk, kanun gereği doğumundan itibaren kendi kişiliğine ve bu bağlamda kişilik hakkına sahiptir ${ }^{60}$. Bununla birlikte burada

${ }^{51}$ Krş., Brauchli, s.25.

${ }^{52}$ Krş., Brauchli, s.25-26; ayrıca bkz., Serozan, N 8.

${ }^{53}$ Brauchli, s.26.

${ }^{54}$ Brauchli, s.26; ayrıca Serozan, N 4.

${ }_{56}^{55}$ Brauchli, s.26-27.

${ }^{56}$ Krş., Brauchli, s. 27.

57 Serozan, N 10; İnan, s.13vd. Bu noktada Birleșmiş Milletler Teşkilatınca kabul edilen Çocuk Haklarına Dair Sözleşme'nin 1. maddesi hükmüne işaret etmek gerekir. Anılan hükme göre: "Bu Sözleşme uyarınca çocuğa uygulanabilecek kanuna göre daha erken yaşta reșit olma durumu hariç, onsekiz yaşına kadar her insan çocuk sayılır" (20 Kasım 1989 tarihli Çocuk Haklarına Dair Sözleşme, Türkiye tarafından 14 Eylül 1990 tarihinde imzalanmıș ve 09.12.1994 tarihli ve 4058 sayılı Kanunla onaylanması uygun bulunarak 23.12.1994 tarihinde Bakanlar Kurulu'nca onaylanması kararlaştııılmıştır, RG.27.01.1995, 22184). Çocuk Haklarına Dair Sözleşme'nin öngördüğü bu istisnai durum, Türk medeni hukuku açısından evlenme yolu ile kazanılan erginlikte (TMK 11/II) ve yargısal erginlikte (TMK 12) söz konusu olmaktadır.

58 Brauchli, s.28vd.; Cyril Hegnauer, Grundriss des Kindesrechts und des übrigen Verwandtschaftsrechts, 5. Auflage, Bern 1999, N 1.01a, N 1.02; Serozan, N 8. Ayrica bkz., TMK 282vd.

${ }^{59}$ Hegnauer, N 1.02; Brauchli, s.29.

${ }^{60} \mathrm{Bu}$ hususta bkz. ve krş., Urs Tschümperlin, Die elterliche Gewalt in Bezug auf die Person 
TMK 28/II hükmüne işaret etmek gerekir. Anılan hükme göre "çocuk hak ehliyetini, sağ doğmak koşuluyla, ana rahmine düştüğü andan başlayarak elde eder". Burada sağ doğma şartına bağlı bir kişilik kazanılması söz konusudur ${ }^{61}$.

\section{IV. Çocuğun Kişiliğinin Ana Babaya Karşı Korunması \\ 1. Çocuğun Kişiliğinin Korunması Gereği ve Çocuğun Kişiliğine Saygı Gösterilmesi İlkesi}

Çocuk, doğumla kişilik kazanır, fakat kendi başına karar verebilen, bağımsız bir insan olarak toplum hayatına katılıncaya kadar uzun süre bakıma, korunmaya ve yönlendirilmeye ihtiyaç duyar ${ }^{62}$. Bu ihtiyacın karşılanması, doğal olarak ve ahlaken ana babanın ödevidir ${ }^{63}$. Nitekim çocuk, prensipte erginliğini elde edinceye kadar ana babanın velayeti altında bulunur $^{64}$. Esasen ana babanın ergin olmayan çocuklarıla ilgili olarak kanunen gerekli kararları alma yetkisini ifade eden velayetin nihai amacı da çocuğa bağımsız bir kişilik kazandırılmasıdır ${ }^{65}$.

Ana baba ve çocuk arasındaki ilişkide her iki taraf da eşit hak süjesi olarak yer alır; diğer bir ifadeyle, çocuğun kişilik hakkı, başlangıçtan itibaren ana babanın kişilik hakkı ile eşdeğerdedir ${ }^{66}$. Bununla birlikte çocuk, daha zayıf bir konumdadır. Şöyle ki; çocuk bedensel, zihinsel, ekonomik ve sosyal yönden güçsüz ve bağımlıdır ${ }^{67}$. Özellikle küçük çocuk, kendi haklı menfaatlerini tek başına koruyabilecek ve zayıf konumunun başkaları, hatta ana baba tarafindan istismar edilmesine karșı mücadele edebilecek durumda değildir $^{68}$. Şu halde çocuğun özel olarak korunması ve bunu sağlayacak haklarla zayıf konumunun güçlendirilmesi gereklidir ${ }^{69}$.

des Kindes (Art.301 bis 303 ZGB), Freiburg 1989, s.97; Cyril Hegnauer, Berner Kommentar zum Schweizerischen Privatrecht, Band II, Das Familienrecht, 2. Abteilung, Die Verwandtschaft, 3. Auflage, 1. Teilband, Das eheliche Kindesverhaeltnis, Art.252-301 ZGB, Bern 1964, aArt.273 N 6; ayrica İnan, s.17.

${ }^{61}$ Dural/Öğüz, s.19. Bu şartın geciktirici veya bozucu şart olup olmadığı hususunda yine bkz., Dural/Öğüz, s.19; Öztan, Şahsın Hukuku, s.13vd., 15; ayrıca Hausheer/Aebi-Müller, Rz 03.14 .

${ }^{62}$ Krş., Hegnauer, N 1.05; David Adam, Kinderschutz, Bern 2001, s.33.

${ }^{63}$ Hegnauer, N 1.05; Adam, s.33.

${ }^{64}$ Hegnauer, N 25.25. Velayetin istisnaen ergin çocuklar üzerinde devam etmesi mümkündür (Bkz., TMK 335/II).

${ }^{65}$ Hegnauer, N 25.02, N 25.03; Tschümperlin, s.49.

${ }^{66}$ BK-Hegnauer, aArt.273 N 6; Brauchli, s.136; Tschümperlin, s.40vd.; Bilge Öztan, Aile Hukuku, 5. Bası, Ankara 2004, s.629-630.

${ }^{67}$ Krş., Serozan, N 5; ayrica bkz., İnan, s.3vd., 10.

${ }^{68}$ Krş., Brauchli, s.136.

${ }^{69}$ Krş., Serozan, N 5, N 6, N 7. 
Çocuğun korunmaya muhtaç ve özel haklarla güçlendirilmesi gereken bir varlık olduğu bilincinin gelişmesiyle birlikte, çocukla ilgili her alanda ve özellikle velayet ilişkisinde çocuğun yararının gözetilmesi temel düşünce olmuştur $^{70}$. Bu suretle çocuğun kişilik hakkına da dikkat çekilmiştir ${ }^{71}$. Öte yandan çocuğun kişiliğine verilen önemin artması ve çocuğun kişiliğinin daha güçlü korunması ihtiyacı sonucunda çocuğun kişiliğine sayg1 gösterilmesi gereği, velayeti yönlendiren ve ana babanın çocukla ilgili karar verme yetkisini sınırlayan bağımsız bir ilke haline gelmiştir ${ }^{72}$.

Çocuğun kişiliğine sayg1 gösterilmesi ilkesi, çocuğun kişiliğinin geliştirilmesi ve korunması gereğini ifade $\operatorname{eder}^{73}$. Bu ilke, İsviçre hukukundaki düzenlemelere paralel olarak Türk Medeni Kanunu'nun çeșitli hükümlerinde somut ifadesini bulmuştur; bu bağlamda özellikle ana baba ve çocuğun karşılıklı sayg1 gösterme yükümlülüğünü öngören TMK 322 ile birlikte velayete ilişkin TMK 339 ve 340 hükümlerine işaret edilmelidir ${ }^{74}$. TMK 339 uyarınca ana baba, olgunluğu ölçüsünde çocuğa hayatını düzenleme imkanı tanımakla ve önemli konularda olabildiğince onun düşüncesini göz önünde tutmakla yükümlüdür. TMK 340 hükmünde ise ana babanın, çocuğun bedensel, zihinsel, ruhsal, ahlaki ve toplumsal gelişimini sağlamakla ve korumakla yükümlü olduğu düzenlenmiştir. Yine aynı hükme göre ana baba, çocuğa, yetenek ve eğilimlerine uygun düşecek ölçüde genel ve mesleki bir eğitim sağlamalıdır. Anılan hükümlerle çocuğun ana baba karşısındaki konumu güçlendirilmiştir ve çocuğun kişiliğinin daha etkili biçimde korunması imkanı yaratılmıştır ${ }^{75}$; zira çocuk, söz konusu hükümler çerçevesinde kişiliğine saygı gösterilmesini, olgunluğu ölçüsünde hayatını düzenleme serbestisinin tanınmasını, düşüncesinin dikkate alınmasını, çok yönlü gelişiminin desteklenmesini, yeteneklerine ve eğilimlerine uygun eğitim sağlanmasını talep edebilecektir ${ }^{76}$.

Ana baba, velayet hakkını amaca uygun ve çocuğun yararını dikkate alarak kullanmalıdır ${ }^{77}$. Velayet ilişkisinde ana babanın çocuğu yönetme yetkisine karşıllk çocuğun ana babanın sözünü dinleme yükümlülüğü

\footnotetext{
${ }^{70}$ Çocuğun yararının velayete hakim en üstün ilkeyi teşkil etmesine ilişkin olarak bkz., Brauchli, s.109vd., 136-137, 162vd.; Tschümperlin, s.81-82; Hegnauer, N 26.04, N 26.04a; Ingeborg Schwenzer, Basler Kommentar zum Schweizerischen Privatrecht (Hrsg., Heinrich Honsell/Nedim Peter Vogt/ Thomas Geiser), Zivilgesetzbuch I, Art.1-456, 2. Auflage, Basel 2002, Art.301 N 4; Serozan, N 75-76; Öztan, s.517, 625vd., 648.

${ }^{71}$ Brauchli, s.136; Tschümperlin, s.95vd.

${ }^{72}$ Krş., Tschümperlin, s.96, 28vd. ; Martin Stettler, SPR, III/2 (Hrsg., Jacques-Michel Grossen), Das Kindesrecht, Basel/Frankfurt a.M. 1992, s.378.

${ }^{73}$ Krş., Tschümperlin, s.95vd.; BSK ZGB I-Schwenzer, Art.301 N 7.

${ }^{74}$ Bu hususta bkz. ve krş., Tschümperlin, s.99vd.; BSK ZGB I-Schwenzer, Art.301 N 7; Brauchli, s.138-139.

${ }^{75}$ Krş., Tschümperlin, s.97, 101; Brauchli, s.139.

76 Krş., Tschümperlin, s.136vd.; Peter Tuor/Bernhard Schnyder/Jörg Schmid/Alexandra Rumo-Jungo, Das Schweizerische Zivilgesetzbuch, 12.Auflage, Zürich 2002, s.436, 437vd.

${ }^{77}$ Hegnauer, N 26.04; Tschümperlin, s.81-82, 86vd.; Brauchli, s.138; Öztan, s.625.
} 
bulunmaktadır $^{78}$. Esasen itaat yükümü, çocuğun gerektiği biçimde eğitilmesine hizmet etmektedir ${ }^{79}$. Ancak çocuğun eğitimi, yukarıdan aşağıya tek yönlü bir ilişki değildir; bilakis ana baba ve çocuğun bütün karşıllklı kişisel temasının sonucudur ${ }^{80}$. Eğitim sürecinde ana baba, çocuğun özgürlüğüne sayg1 göstermeli, çocuğun somut olaydaki mukavemetini bastırmamalı, çocuğun onurunu zedelememelidir ${ }^{81}$. Şu halde çocuk, ana babaya teslim edilmiş obje değildir ${ }^{82}$. Ana baba, çocuğu hak süjesi olarak idrak etmeli ve çocuğun kişiliğine değer vererek çocuğun kişiliğini korumalıdır ${ }^{83} . \mathrm{Bu}$ bağlamda ana baba, velayetten doğan yetkilerine dayanarak velayetin amaca uygun ve gereği gibi yürütülmesi için zorunlu olanın dışında çocuğun kişiliğine müdahalede bulunamaz, çocuğun yararını tehlikeye düşüremez ${ }^{84}$. Aksi takdirde çocuğun korunmasına yönelik önlemlerin alınması yoluna gidilir ${ }^{85}$; keza dava şartlarının oluşması halinde kişiliği koruyucu genel hükümler çerçevesinde bizzat çocuğun da ana baba karşısında kişiliğinin korunmasını talep hakkı mevcuttur ${ }^{86}$.

\section{Türk Medeni Kanunu'nun 346 vd. Hükümleri Çerçevesinde Çocuğun Kişiliğinin Korunması}

\section{a. Genel Olarak}

Türk Medeni Kanunu'nun 346 vd. hükümlerinde çocuğun kişiliğinin ana babaya karşı korunmasına yönelik önlemlere yer verilmiştir ${ }^{87}$. Çocuğu koruyucu önlemlere, çocuğun yararının tehlikeye düşmesi halinde başvurulur $^{88}$. Bu önlemlerle ana babanın velayet hakkına müdahale edilerek,

\footnotetext{
${ }^{78}$ Hegnauer, N 26.03; ayrica Öztan, s.648vd.

${ }^{79}$ Krş., Hegnauer, N 26.03; Tschümperlin, s.333vd.; Öztan, s.648.

${ }^{80}$ Krş., BSK ZGB I-Schwenzer, Art.301 N 7; Tschümperlin, s.222; BBl 1974 II 76.

${ }^{81}$ Krş., BSK ZGB I-Schwenzer, Art.301 N 7; BB1 1974 II 76.

${ }^{82}$ Brauchli, s.138; BK-Hegnauer, aArt.273 N 6; Öztan, s.629.

${ }^{83}$ Krş., Tschümperlin, s.96, 82; ayrıca Brauchli, s.138.

${ }^{84}$ Krş., Tschümperlin, s.109-110, 121, 139vd., 315.

${ }^{85} \mathrm{Bu}$ hususta bkz. ve krș., Hegnauer, N 27.02vd., N 27.14vd.; Tschümperlin, s.86, 121, 139vd., 315; Brauchli, s.137, 171vd.; Öztan, s.669vd., 642vd.; ayrıca Serozan, N 246vd., N 251, N 281.

${ }^{86}$ Krş., Tschümperlin, s.111vd.

${ }^{87}$ Krş., Mustafa Dural/Tufan Öğüz/Alper Gümüş, Türk Özel Hukuku, Cilt III, Aile Hukuku, İstanbul 2005, s.528vd.; Turgut Akıntürk, Türk Medeni Hukuku, Yeni Medeni Kanuna Uyarlanmış Aile Hukuku, 2.Cilt, 6.Bası, İstanbul 2002, s.429vd.; ayrıca Bülent Köprülü/Selim Kaneti, Aile Hukuku, 2. Bası, İstanbul 1989, s.256vd.; Çocuğun kişiliğinin korunmasına yönelik önlemler, kaynak İsviçre Medeni Kanunu'nun Art.307vd. hükümlerinde düzenlenmiştir. Bu hususta bkz., Tuor/Schnyder/Rumo-Jungo, s.444; Helmut Henkel, Die Anordnung von Kindesschutzmassnahmen gemäss Art.307 rev. ZGB, Zürich 1977, s.56.

${ }^{88}$ Hegnauer, N 27.02, N 27.09; Peter Breitschmid, Basler Kommentar zum Schweizerischen Privatrecht (Hrsg., Heinrich Honsell/Nedim Peter Vogt/Thomas Geiser), Zivilgesetzbuch I, Art.1-456, 2.Auflage, Basel 2002, Art.307 N 1, N 4; Tuor/Schnyder/Rumo-Jungo, s.445; Marlies Näf-Hofmann, "Kindesschutz und Pflegeeltern", Das neue Kindesrecht, St. Gallen
} 
çocuğun yararına yönelik tehlikenin giderilmesi ve çocuğun korunması amaçlanır $^{89}$. Bu bağlamda ifade edilmelidir ki çocuğu koruyucu önlemlerin alınması, ana babanın kusurunu gerektirmez; keza bu önlemler, ana babanın davranışının yaptırımı niteliğinde de değildir ${ }^{90} 91$.

Doktrinde çocuğun özellikle TMK 339 ve 340 hükümlerine göre ana baba karşısında kişiliğine saygı gösterilmesine ilişkin olarak ileri sürebileceği taleplerin, çocuğu koruyucu önlemler vasitasiyla gerçekleştirilebileceği ifade edilmektedir ${ }^{92}$. Bu çerçevede mesela çocuğun ana babasıyla duygusal bağının devamı veya korunmasına yönelik talebinin, çocuğu koruyucu önlemlere başvurulmak suretiyle gerçekleştirilmesi mümkündür ${ }^{33}$.

Çocuğu koruyucu önlemlere başvurulurken belirli ilkelerin göz önünde bulundurulması gereklidir ${ }^{94}$. Buna göre, çocuğun yararına yönelik tehlikenin giderilmesini hedefleyen çocuğu koruyucu önlemler, çocuğun yararının gözetilmesinden öncelikle ana babanın sorumlu olduğu esasından hareketle

1977, s.80; krş., Henkel, s.35vd., 64; Adam, s.41-42; Silvia Däppen-Müller, Kindsmisshandlung und -vernachlässigung aus straf- und zivilrechtlicher Sicht, Zürich 1998, s.72; ayrıca Tschümperlin, s.139vd.; Öztan, s.670-671.

${ }^{89}$ Krş., Hegnauer, $\mathrm{N}$ 27.08; BSK ZGB I-Breitschmid, Art.307 N 1, N 4; Tuor/Schnyder/Rumo-Jungo, s.444; Henkel, s.66; Tschümperlin, s.140; Öztan, s.669vd.

${ }^{90}$ Hegnauer, N 27.09; BSK ZGB I-Breitschmid, Art.307 N 4; Tuor/Schnyder/Rumo-Jungo, s.445; Öztan, s.670; krş., Henkel, s.65; Näf-Hofmann, s.80, 82vd.; Akıntürk, s.431.

${ }^{91} \mathrm{Bu}$ noktada 4320 sayıl1 Ailenin Korunmasına Dair Kanun (Bkz., dn.1)'da yer alan düzenlemeye işaret etmek gerekir. Bu Kanun'a göre, Türk Medeni Kanunu'nda öngörülen önlemlerden ayrı olarak, eşlerden birinin veya çocukların ya da aynı çatı altında yaşayan diğer aile bireylerinden birinin aile içi şiddete maruz kaldığını kendilerinin veya Cumhuriyet Başsavcılığının bildirmesi halinde, Aile Mahkemesi Hakimi, re'sen meselenin mahiyetini göz önünde bulundurarak anılan Kanun'da sayılan önlemlerden bir veya bir kaçına birlikte veya uygun göreceği benzeri başkaca önlemlere de hükmedebilir. Bu önlemler: Kusurlu eşin, diğer eşe veya çocuklara veya aynı çatı altında yaşayan diğer aile bireylerine karşı şiddete veya korkuya yönelik davranışlarda bulunmaması; müşterek evden uzaklaştırılarak bu evin diğer eşe ve varsa çocuklara tahsisi ile diğer eş ve çocukların oturmakta olduğu eve veya işyerlerine yaklaşmaması; diğer eşin, çocukların veya aynı çatı altında yaşayan diğer aile bireylerinin eşyalarına zarar vermemesi; diğer eşi, çocukları veya aynı çatı altında yaşayan aile bireylerini iletişim vasıtalarıyla rahatsız etmemesi; varsa silah ve benzeri araçlarını zabıtaya teslim etmesi; alkollü veya uyuşturucu herhangi bir madde kullanılmış olarak ortak konuta gelmemesi veya ortak konutta bu maddeleri kullanmaması (m.1). Kanun'da anılan önlemlerin tatbiki maksadıyla öngörülen sürenin altı ayı geçemeyeceği ve kararda hükmolunan önlemlere aykırı davranılması halinde tutuklanacağı ve hürriyeti bağlayıcı cezaya hükmedileceği hususunun kusurlu eşe ihtar olunacağı hükmü de yer almaktadır (Ailenin Korunmasına Dair Kanun'a iliş̧in olarak bkz., Zevkliler/Acabey/Gökyayla, s.767vd.; Mehmet Ali Uçar, Aile İçi SSiddet ve Aile Koruma Yasas1, Ankara 2003, s.133vd.; Dural/Öğüz/Gümüş, s.295vd.).

${ }^{92}$ Krş., Tschümperlin, s. 142.

${ }^{93}$ Krş., Tschümperlin, s.106; Hausheer/Aebi-Müller, Rz 12.83; Bucher, N 471.

${ }^{94}$ Bu hususta bkz. ve krş., Hegnauer, N 27.09vd.; BSK ZGB I-Breitschmid, Art.307 N 4vd.; Tuor/Schnyder/Rumo-Jungo, s.444vd.; Stettler, s.498vd.; Adam, s.42vd.; Däppen-Müller, s.71; Näf-Hofmann, s.80vd.; ayrıca Henkel, s.61vd.; Öztan, s.670-671. 
sadece ana babanın kendilerine düşen ödevleri hiç veya yeterli biçimde yerine getirmediği yerde vuku bulmalıdır; şu halde ana baba, çocuğun yararını tehlikeye düşüren duruma kendiliğinden çare bulmazsa veya buna güçleri yetmezse çocuğu koruyucu önlemlerin alınması yönüne gidilir $(\text { Talilik ilkesi }=\text { Subsidiaritätsprinzip })^{95}$. Keza çocuğu koruyucu önlemler, ana babanın mevcut yeteneklerini tamamlamalıdır; ana babadaki eksikliği dengelemelidir $(\text { Tamamlayıc1lk ilkesi }=\text { Komplementaritätsprinzip })^{96}$. Öte yandan çocuğu koruyucu önlemler, tehlikenin derecesine uygun olmalıdır; bu bağlamda ana babanın velayet hakkını mümkün olduğu kadar az, fakat gerektiği kadar çok sınırlamalıdır (Ölçülülük ilkesi = Proportionalitätsprinzip) ${ }^{97}$.

Çocuğu koruyucu önlemler, her ilgilinin başvurusu üzerine veya çocuğun yararını tehlikeye düşüren halden haberdar olması halinde hakim tarafindan re'sen alınabilir ${ }^{98}$.

Türk Medeni Kanunu'nun 346 vd. hükümleri çerçevesinde çocuğu koruyucu önlemler, ana babanın velayet hakkına, ağırlıklarına göre sıralanan üç müdahaleyi içermektedir ${ }^{99}$ : Koruma önlemleri (TMK 346), çocukların yerleştirilmesi (TMK 347), velayetin kaldırılması (TMK 348-350). Bu önlemler, aşağıda ele alınacaktır. Öte yandan ifade etmek gerekir ki çocuğun korunmasına yönelik önlemlerin alınmasına yol açan durumun değişmesi halinde, söz konusu önlemlerin yeni şartlara uyarlanması gerekir (TMK 351).

\section{b. Koruma Önlemleri (TMK 346)}

Türk Medeni Kanunu'nun 346. maddesine göre, “çocuğun menfaati ve gelişmesi tehlikeye düştüğü takdirde, ana ve baba duruma çare bulamaz veya buna güçleri yetmezse hakim, çocuğun korunması için uygun önlemleri alır". Kanımızca madde metninde yer alan çocuğun menfaati ve gelişmesinin tehlikeye düşmesinden maksat, doktrindeki yaklaşımlar ve kaynak İsviçre Medeni Kanunu'ndaki düzenleme (Art.307 ZGB) göz önünde bulundurulduğunda, çocuğun yararının tehlikeye düşmesidir ${ }^{100}$. Çocuğun yararı, her durumda çocuğun bedensel, zihinsel, ruhsal, ahlaki ve toplumsal yönden optimal gelişimini sağlayacak şartların olabildiğince iyi teşekkül

\footnotetext{
${ }^{95}$ Hegnauer, N 27.10; BSK ZGB I-Breitschmid, Art.307 N 6; Adam, s.42.

${ }^{96}$ Hegnauer, N 27.11; BSK ZGB I-Breitschmid, Art.307 N 7; Adam, s.42.

${ }^{97}$ Hegnauer; N 27.12; BSK ZGB I-Breitschmid, Art.307 N 8; Däppen-Müller, s.71; Adam, s.43; Tuor/Schnyder/Rumo-Jungo, s.445vd.; Öztan, s.670vd.

${ }_{98} \mathrm{Krş.,} \mathrm{Dural/Ögüü/Gümüş,} \mathrm{s.529;} \mathrm{Akıntürk,} \mathrm{s.430;} \mathrm{ayrıca} \mathrm{Köprülü/Kaneti,} \mathrm{s.256;} \mathrm{Serozan,} \mathrm{N}$ 281; bu hususta örnek bir karar için bkz., Yargitay 2. Hukuk Dairesi'nin 22.10.2001 tarihli ve Esas 2001/12325, Karar 2001/14301 say1l1 Karar1 (RG.18.11.2001, S.24587).

${ }^{99}$ Öztan, s.671; İsviçre hukuku bakımından krş., Hegnauer, N 27.08.

100 Öztan, s.671vd.; Hegnauer, N 27.14; BSK ZGB I-Breitschmid, Art.307 N 14; Tuor/Schnyder/Rumo-Jungo, s.447; Henkel, s.64; Brauchli, s.171; Tschümperlin, s.139vd.
} 
ettirilmesini gerektirir ${ }^{101}$. Bu noktada çocuğun içinde bulunduğu şartlara göre çocuğun yararının zedelenebileceğine dair ciddi bir ihtimalin öngörülmesi halinde, çocuğun yararına yönelik bir tehlikeden söz edilir ${ }^{102}$. Koruma önlemlerine başvurabilmek için bu ihtimalin gerçekleşmiş olması şart değildir ${ }^{103}$. Öte yandan tehlikenin hangi sebepten doğduğu önemsizdir; tehlikeye ana baba veya çocuğun davranışı ya da yetenekleri veya çevre vb. yol açabilir ${ }^{104}$. Somut olayda çocuğun bedensel yararı tehlikeye düşmüş olabilir; mesela ana babanın bedensel cezalandırma yoluyla çocuğa kötü muamelede bulunması halinde böyle bir tehlikenin varlığından söz etmek mümkündür ${ }^{105}$. Keza çocuğun zihinsel, ruhsal, ahlaki veya toplumsal yararı da tehlikeye düşebilir (Mesela çocuğa karşı duygusuz, merhametsiz davranışların sergilenmesi; velayeti altında bulunmayan veya kendisine bırakılmayan çocukla kişisel ilişki kurma hakkına sahip ana ya da babayla veya diğer yakın kişilerle çocuğun temasının zorlaştırılması; öğrenme güçlüğü çeken çocukla yeterince ilgilenilmemesi; çocuğun sosyal izolasyonu; ana babanın ahlaken tutarsız tavirlarda bulunması gibi hallerde) ${ }^{106}$.

Çocuğun yararı tehlikeye düştüğü takdirde ve ana babanın bu tehlikeyi gidermek üzere çare temin etmediği veya buna güçlerinin yetmediği durumda hakim, çocuğun korunması için uygun önlemleri alacaktır ${ }^{107}$. Türk Medeni Kanunu, uygun önlemlerin neler olabileceğini belirtmemiştir; şu halde somut olayda çocuğun yararına yönelik tehlikeyi bertaraf etmek ve çocuğu korumak üzere hangi önlemlerin alınabileceği hakimin takdirine bırakılmıştır ${ }^{108}$. Kaynak İsviçre Medeni Kanunu'nda ise bu husustaki düzenlemeyi öngören Art.307 hükmünde örnek kabilinden bazı önlemlere işaret edilmiştir ${ }^{109}$. Buna göre uygun önlemler bağlamında vesayet makamı, ana babayı veya çocuğu uyarabilir; onlara çocuğun bakımı veya eğitimi konusunda belirli talimatlar verebilir; keza çocuğun gelişimini gözlemlemek veya vesayet makamının talimatlarının yerine getirilip getirilmediğini kontrol etmek üzere gereğinde ana baba tarafindan kendisine bilgi verilecek bir kişiyi veya mercii görevlendirebilir. $\mathrm{Bu}$ önlemlerle çocuğa yönelik tehlikenin, çocuğu başka yere yerleştirmeden kendi ailesinin yanında veya

\footnotetext{
${ }^{101}$ Krş., Hegnauer, N 26.04a; Tschümperlin, s.84; Tuor/Schnyder/Rumo-Jungo, s.437, dn.48; ayrica bkz., TMK 340/I.

${ }^{102}$ Krş., Hegnauer, N 27.14.

${ }^{103}$ Hegnauer, N 27.14; krș., Tuor/Schnyder/Rumo-Jungo, s.447; Henkel, s.64; Öztan, s.671.

${ }^{104} \mathrm{Krş.,} \mathrm{Hegnauer,} \mathrm{N} \mathrm{27.14.}$

${ }^{105}$ Krş., BSK ZGB I-Breitschmid, Art.307 N 18; ayrıca bkz., Henkel, s.40.

${ }^{106}$ Krş., BSK ZGB I-Breitschmid, Art.307 N 18; Öztan, s.671.

107 Öztan, s.671-672; krş., Hegnauer, N 27.14; BSK ZGB I-Breitschmid, Art.307 N 14; Tuor/Schnyder/Rumo-Jungo, s.447; Henkel, s.64vd.

${ }_{108}$ Öztan, s.672; Akıntürk, s.430; Dural/Öğüz/Gümüş, s.529.

${ }^{109}$ Bu hususta bkz., Hegnauer, N 27.16, N 27.17; BSK ZGB I-Breitschmid, Art.307 N 19vd.; Tuor/Schnyder/Rumo-Jungo, s.447-448; Stettler, s.499vd.; Henkel, s.69vd.; Tschümperlin, s.140vd.; Adam, s.45vd.; Däppen-Müller, s.72vd.; Näf-Hofmann, s.82vd.
} 
halihazırda bulunduğu ortamda giderilmesi amaçlanmaktadır ${ }^{110}$. İsviçre doktrininde Art.307 ZGB hükmü anlamında uygun önlem olarak ana babanın uyarılması yönüne gidilmesi halinde, bunun velayet hakkını sınırlamayacağı ifade edilmektedir; buna karşılık ana babaya belirli talimatlar verilmesi durumunda, talimat kapsamında ana babanın çocukla ilgili karar alma yetkisi sınırlanmaktadır ${ }^{111}$. Çocuğun gelişimini gözlemlemek veya vesayet makamının talimatlarına riayet edilip edilmediğini kontrol etmek üzere belirli bir kişi veya merciin görevlendirilmesi halinde ise, ana babanın kendilerinden istenildiği takdirde söz konusu kişi veya mercie bilgi vermekle yükümlü olması bakımından velayet hakk1 sınırlanmaktadır ${ }^{112}$. Belirtilmelidir ki burada ilgili kişi veya merci, vesayet makamının yardımcısı durumundadır; bağımsız yetkilere sahip değildir, vesayet makamının direktifleri doğrultusunda hareket eder, gözlemlerinin sonuçlarını vesayet makamına bildirir ve gerekli gördüğü takdirde çocuğu koruyucu diğer önlemlerin alınmasını talep eder ${ }^{113}$.

Türk hukuk doktrininde TMK 346 hükmü çerçevesinde çocuğun korunmasına yönelik önlemlerin alınmasının gerekli olduğu hallerde hakimin, kaynak İsviçre Medeni Kanunu'nun bu husustaki düzenlemesinden (Art.307 ZGB) yararlanabileceği ve benzer önlemlere karar verebileceği bazı yazarlar tarafindan kabul edilmektedir ${ }^{114}$.

\section{c. Cocukların Yerleștirilmesi (TMK 347)}

Türk Medeni Kanunu'nun 347. maddesinin birinci fikrasına göre, "çocuğun bedensel ve zihinsel gelişmesi tehlikede bulunur veya çocuk manen terk edilmiş halde kalırsa hakim, çocuğu ana ve babadan alarak bir aile yanına veya bir kuruma yerleştirebilir". Doktrinde çocuğun bedensel ve zihinsel gelişimi bakımından sözü edilen tehlikenin, nitelikli bir tehlike

\footnotetext{
${ }^{110}$ Krş., Hegnauer, N 27.16.

${ }^{111}$ Tschümperlin, s.140-141; Henkel, s.57, 81; ayrıca BK-Hegnauer, aArt.283 N 118, N 121.

112 Tschümperlin, s.140; ayrıca BK-Hegnauer, aArt.283, N 132; krş., Henkel, s.57.

${ }^{113}$ Hegnauer, N 27.17; Tuor/Schnyder/Rumo-Jungo, s.448; Henkel, s.77vd.; Näf-Hofmann, s.84.

${ }_{114} \mathrm{Bu}$ hususta bkz., Öztan, s.672. İsviçre Medeni Kanunu'nda çocuğu koruyucu önlemler arasında, çocuğa bir kayyım atanabileceği de öngörülmüştür ( Art.308/309 ZGB). Art.308 ZGB hükmüne göre şartlar gerektirdiği takdirde, bu bağlamda çocuğun yararına yönelik tehlikenin Art.307 ZGB'deki uygun önlemlerle (Krş., TMK 346) giderilememesi halinde vesayet makamı, çocuğa bir kayyım atar. Bu kayyım, ana babayı çocuğun eğitimi ve bakımı konusunda tavsiye ve eylemle destekler; vesayet makamı, gerekli görürse kayyıma özel yetkiler devredebilir ve bu çerçevede ana babanın velayet hakkını sınırlayabilir. Art.309 ZGB hükmünde ise evlilik dışı çocuğun babasıyla soybağını tespit etmek ve anneye gereken şekilde yardımcı olmak üzere çocuğa kayyım atanması hususu düzenlenmiştir. Çocuğa kayyım atanmasına iliş̧in olarak bkz., Hegnauer, N 27.19vd., N 27.25vd.; BSK ZGB I-Breitschmid, Art.308 N 1vd., Art.309 N 1vd. Öztan' a göre Türk Medeni Kanunu'nda çocuğu koruyucu önlemler arasında, Art.308 ZGB hükmüne benzer şekilde çocuğun kişiliğinin korunması ve/veya eğitiminin sağlanması için kayyım atanmasına imkan verilmesi, Kanun'un çocuk hukuku ile ilgili düzenlemesindeki ana fikre uygun düşerdi (s.674).
} 
olduğu ifade edilmektedir ${ }^{115}$. Bu bağlamda çocuğa yönelik tehlike, TMK 346 hükmü çerçevesinde öngörülen koruma önlemleriyle giderilemeyecek derecede ağır olmalıdır ve bu tehlikenin bertaraf edilebilmesi için çocuğun ana babadan alınması gerekli görülmelidir ${ }^{116}$. Öte yandan doktrinde tehlikenin süreklilik göstermesi gereğine işaret edilmektedir ${ }^{117}$. Burada tehlikenin sebebi önemli değildir; tehlike, ana babanın davranışından veya yeteneklerinden ya da çocuktan veya diğer sebeplerden kaynaklanabilir ${ }^{118}$. Mesele şudur ki çocuk, ana babanın yanında bedensel ve zihinsel gelişimi için gerekli koruma ve destekten yoksun kalmaktadır ve bundan dolayı tehlikededir $^{119}$. TMK 347 hükmünde çocuğun sadece bedensel ve zihinsel gelişiminin tehlikeye düşmesinden söz edilmiş olmakla birlikte, kanımızca çocuğun ruhsal, ahlaki ve/veya toplumsal gelişiminin tehlikede bulunması halinde de, gerekli görüldüğg̈ takdirde çocuğun ana babadan alınması yönüne gidilebilmelidir (Krş., TMK 340/I). Esasen burada çocuğun yararının çeşitli yönleriyle veya genel olarak tehlikeye düşmesi ölçütünden hareket edilmelidir ${ }^{120}$.

TMK 347/I hükmünde ana babadan alınabilmesi için çocuğun tehlikede bulunmasının yanı sıra çocuğun manen terk edilmiş halde kalmasından da söz edilmektedir. Doktrinde bu hüküm uyarınca çocuğun sürekli tehlikede bulunması ile çocuğun manen terk edilmiş halde kalması arasındaki sınırın kesin çizgilerle ayrılmasının mümkün olmadığı ifade edilmektedir ${ }^{121}$. Hegnauer'e göre çocuğun manen terk edilmiş halde kalması, bertaraf edilmemiş ya da çabalara rağmen bertaraf edilememiş olan sürekli tehlikenin sonucudur $^{122}$. Bu noktada çocuğun kişiliğinin uyumlu gelişimi kesintiye uğramıştır; çocuğun yararı, bedensel ve zihinsel gelişiminin tehlikede bulunmasından farklı olarak zarar görmüştür ${ }^{123}$. Bu nedenle manen terk, halihazırda zarar ortaya çıkmış olduğundan, çocuğun bedensel ve zihinsel

\footnotetext{
${ }^{115}$ Krş., BK-Hegnauer, aArt.284 N 5; Näf-Hofmann, s.93.

${ }^{116}$ Krş., BK-Hegnauer, aArt.284 N 5, N 6vd., N 11vd.; Hegnauer, N 27.36; Näf-Hofmann, s.92, 93vd.; Adam, s.51; BSK ZGB I-Breitschmid, Art.310 N 3vd.; Öztan, s.675; Kemal Oğuzman/Mustafa Dural, Aile Hukuku, İstanbul 1994, s.304vd.

${ }^{117}$ Krş., BK-Hegnauer, aArt.284 N 9; Öztan, s.675, 676; Oğuzman/Dural, s.305; Dural/Öğüz/Gümüş, s.529; fakat bkz., A. Egger, Zürcher Kommentar zum Schweizerischen Zivilgesetzbuch, II. Band, Das Familienrecht, 2. Abteilung, Die Verwandtschaft, Art.252-359, 2. Auflage, Zürich 1943, aArt.284 N 3; Ali Naim İnan, "Özel (Medeni) Hukuk Bakımından Ana-Baba İle Çocuk İlişkileri ve Çocukların Ana-Babaya Karşı Korunması”, Prof. Dr. Hamide Topçuoğlu'na Armağan, Ankara 1995, s.29; Emine Akyüz, "Medeni Kanuna Göre Çocuğun Ana-Babasına Karşı Korunması”, Aile ve Toplum, Haziran 1991, s.39.

${ }_{118}$ Krş., Öztan, s.677; Oğuzman/Dural, s.305; ayrıca bkz., BK-Hegnauer, aArt.284 N 15, N $16 \mathrm{vd}$.

${ }^{119} \mathrm{Krş.,} \mathrm{Hegnauer,} \mathrm{N} \mathrm{27.36;} \mathrm{Adam,} \mathrm{s.51.}$

${ }^{120}$ Krş., BK-Hegnauer, aArt.284 N 15-19.

${ }^{121}$ Krş., BK-Hegnauer, aArt.284 N 22; Öztan, s.677; Oğuzman/Dural, s.307.

${ }^{122}$ Krş., BK-Hegnauer, aArt.284 N 22; Oğuzman/Dural, s.307.

${ }^{123}$ Krş., BK-Hegnauer, aArt.284 N 22.
} 
gelişiminin tehlikede bulunması durumundan daha kolay tespit edilebilir olgudur ${ }^{124}$.

Öte yandan çocukların yerleştirilmesine ilişkin olarak 347. maddenin ikinci fikrasında da şu düzenleme öngörülmüştür: "Çocuğun aile içinde kalması ailenin huzurunu onlardan katlanmaları beklenemeyecek derecede bozuyorsa ve durumun gereklerine göre başka çare de kalmamışsa, ana ve baba veya çocuğun istemi üzerine hakim aynı önlemleri alabilir”. Bu fikra hükmü yorumlanırken kaynak İsviçre Medeni Kanunu'nun bu husustaki düzenlemesinin (Art.310 Abs.2) de göz önünde bulundurulmasının isabetli olacağ 1 görüşündeyiz ${ }^{125}$. Bu bağlamda ailenin huzurunun bozulması, ana baba ve çocuk arasındaki ilișkinin zedelenmesi olarak ifade edilebilir. Buna göre TMK 347/II hükmü ile ana baba ve ayırt etme gücüne sahip çocuğa, aralarındaki karşılıklı ilişkinin aile içinde birlikte yaşamayı imkansız kılacak derecede zedelenmesi halinde, ayrı yaşamak üzere hakime başvurma imkanı tanınmıștır ${ }^{126}$. Doktrinde ana baba ve çocuk arasında zedelenen ilișkinin çocuğun gelişimini tehlikeye düşüreceği bütün haller, bu hükmün kapsamında değerlendirilmektedir ${ }^{127}$. Kanımızca TMK 347/II hükmünde öngörülen durumdan kimin sorumlu olduğu önemsizdir ${ }^{128}$. Doktrinde belirtildiği üzere bu durumda çocuğun ana babadan alınması, şartlara göre çocuğun veya ana babanın kişiliğinin korunmasına da hizmet eder ${ }^{129}$.

TMK 347 hükmünde öngörülen koşulların gerçekleşmesi halinde çocuk, hakim tarafindan ana babadan alınarak bir aile yanına veya bir kuruma yerleştirilebilir. Çocukların yerleştirilmesine ilişkin olarak daha farklı bir düzenleme öngören İsviçre Medeni Kanunu'nda ana babadan alınan çocuğun sadece uygun biçimde yerleștirilmesinden söz edilmiștir (Art.310 Abs.1 ZGB). Bu bağlamda doktrinde çocuğun yerleştirilmesine ilișkin olarak, aile veya kurum dıșındaki ihtimallerin de söz konusu olabileceği ifade edilmektedir ${ }^{130}$; buna göre çocuk, uygun bir kişinin yanına

\footnotetext{
${ }^{124}$ BK-Hegnauer, aArt.284 N 23.

125 Kaynak İsviçre Medeni Kanunu'nun Art.310 Abs.2 hükmünün Almanca metninde öngörülen düzenleme uyarınca, ana baba ve çocuk arasındaki ilişki, çocuğun aile içinde kalmasının beklenemeyeceği derecede zedelenmişse ve şartlara göre başka türlü yardımda bulunulamıyorsa, ana baba veya çocuğun istemi üzerine vesayet makamı, çocuğu ana babadan alarak uygun biçimde yerleştirir (Krş., Art.310 Abs.1).

${ }^{126}$ Krş., BSK ZGB I-Breitschmid, Art.310 N 22.

${ }^{127}$ Krş., Hegnauer, N 27.37; Stettler, s.512; Tschümperlin, s.184; ayrıca Adam, s.52.

$128 \mathrm{Bu}$ hususta bkz., Adam, s.52; krș., Öztan, s.677; Akıntürk, s.408. Türk Medeni Kanunu'nun 347. maddesiyle ilgili olarak gerekçede (Bkz., TBMM Tutanak Dergisi, Dönem 21, Yasama Y1l 4, Cilt 73 [Ankara 2001], Birleşim 11-12, S. Sayısı 723, s.128), eski Medeni Kanun'daki metne (Bkz., eski MK 273) göre hüküm değişikliği bulunmadığı ifade edilmektedir.

${ }^{129}$ Hegnauer, N 27.37; Adam, s.52; Stettler, s.512; Tschümperlin, s.184; ayrıca bkz., BBl 1974 II 83; krş., Öztan, s.675.

130 Hegnauer, N 27.41; Adam, s.53vd.; BSK ZGB I-Breitschmid, Art.310 N 8vd.; Tuor/Schnyder/Rumo-Jungo, s.452; ayrıca bkz., Öztan, s.675.
} 
yerleştirilebilir veya erginliğe yakınsa bağımsız oturabilir. Her halükarda çocuğun yerleştirilmesinde önemli olan, çocuğun yararının ve kişiliğinin göz önünde bulundurulmasıdır ${ }^{131}$. Bu yönde ayırt etme gücüne sahip çocuğun görüşü de alınmalıdır ${ }^{132}$.

TMK 347 hükmü çerçevesinde çocuğun ana babadan alınarak ${ }^{133}$ uygun biçimde yerleştirilmesi halinde ana babanın çocuk üzerindeki velayet hakkı devam etmekle birlikte, çocuğun kalacağı yeri belirleme ve çocuğun bakımı ve eğitimiyle doğrudan ilgilenme hakkı kaldırılmaktadır (Krş., TMK 339/I, IV $)^{134}$. Doktrinde ifade edildiği üzere çocuğun ana babadan alınması, Avrupa İnsan Hakları Sözleşmesi'nin 8. maddesi ile güvenceye bağlanmış ana babalık hakkına ağır bir müdahaledir; bu sebeple ancak çocuğa yönelik tehlikeye göre ölçülü olduğu takdirde hukuken uygun bir önlem niteliğini $\operatorname{taş11^{135}}$.

\section{d. Velayetin Kaldırılması (TMK 348-350)}

Velayetin kaldırılması, çocuğu korumaya yönelik önlemlerin en radikalidir $^{136}$. Bu önlem, ana babanın velayet hakkına en ağır müdahaleyi oluşturur; bu sebepledir ki velayetin kaldırılması, sıkı şartlara bağlanmıştır ${ }^{137}$. TMK 348 hükmü uyarınca hakim tarafından velayetin kaldırılmasına karar verilebilmesi için, anılan hükümde öngörülen hallerden birinin varlığ 1 aranmakla birlikte, çocuğu koruyucu diğer önlemlerden (Bkz., TMK 346, 347) sonuç alınamamış ya da bu önlemlerin yetersiz kalacağının önceden anlaşılmış olması gereklidir ${ }^{138}$.

TMK 348 hükmünde velayetin kaldırılmasına sebep teşkil eden haller incelendiğinde, burada genel olarak velayetin yürütülmesinde ana babanın süreklilik gösteren fiilî bir ehliyetsizliğinin arandığını söylemek

\footnotetext{
${ }^{131}$ Hegnauer, N 27.41; Adam, s.53; ayrıca Öztan, s.675.

${ }^{132}$ Hegnauer, N 27.41; krş., TMK 339/III; Çocuk Haklarına Dair Sözleşme (Dn.57), m.12.

133 Çocuğun ana baba tarafından bir üçüncü kişiye bırakılması mümkündür. Böyle bir ihtimalde de TMK 347 hükmünde öngörülen koşulların gerçekleşmesi halinde, çocuğun uygun biçimde yerleştirilmesi yönüne gidilebilmelidir (Krş., Öztan, s.675). TMK 347'de düzenlenmemiş olan bu husus, kaynak İsviçre Medeni Kanunu'nun Art.310 Abs.1 hükmünde yer almaktadır. Bkz., Hegnauer, N 27.36; Tuor/Schnyder/Rumo-Jungo, s.452.

${ }_{134}$ Krş., Hegnauer, N 27.44; Tschümperlin, s.185; Richard Frank, "Grenzbereiche der elterlichen Gewalt", Festschrift für Cyril Hegnauer zum 65.Geburtstag, Bern 1986, s.40; BSK ZGB I-Breitschmid, Art.310 N 1; ayrıca Öztan, s.676; Oğuzman/Dural, s.307.

${ }^{135}$ Hegnauer, N 27.36; krş., BSK ZGB I-Breitschmid, Art.310 N 2; Tuor/Schnyder/RumoJungo, s.452.

${ }^{136}$ Adam, s.54; BSK ZGB I-Breitschmid, Art.311/312 N 3; ayrıca krş., Serozan, N 281.

${ }^{137}$ Adam, s.54; Akıntürk, s.432vd.; Öztan, s.678.

138 Öztan, s.640, 642vd., 678; Akıntürk, s.433vd.; krş., Hegnauer, N 27.46; Adam, s.54; Stettler, s.515, 516vd.; Tuor/Schnyder/Rumo-Jungo, s.454; BSK ZGB I-Breitschmid, Art.311/312 N 3, N 6-8.
} 
mümkündür ${ }^{139}$. Buna göre ana babanın deneyimsizliği, hastalığı, özürlü olması, başka bir yerde bulunması veya benzeri sebeplerden biriyle velayet görevini gereği gibi yerine getirememesi halinde, bu durum mevcuttur (TMK 348/I, b.1). Doktrinde ana babanın velayeti ifadaki yetersizliğine yol açan bu haller, velayetin kaldırılmasını gerektiren objektif sebepler olarak ifade edilmektedir ${ }^{140}$. Burada sayılan sebepler sınırlı değildir ${ }^{141}$. Öte yandan ana babanın velayeti yerine getirmedeki ehliyetsizliği, onların davranışından da ileri gelebilili ${ }^{142}$. Bu husus, TMK 348/I, b.2 hükmünde öngörülmüştür; bu bağlamda ana babanın çocuğa yeterli ilgiyi göstermemesi veya ona karşı yükümlülüklerini ağır biçimde savsaklaması halinde, velayetin kaldırılması yönüne gidiliir ${ }^{143}$. Belirtilmelidir ki ana babanın kusuru şart değildir ${ }^{144}$.

Hakim, velayetin kaldırılması esnasındaki şartları esas almalıdır ${ }^{145}$. Velayet ana babanın her ikisinden kaldırılırsa çocuğa bir vasi atanır (TMK 348/II; ayrıca bkz., TMK 349). Kararda aksi belirtilmedikçe, velayetin kaldırılması mevcut ve doğacak bütün çocukları kapsar (TMK 348/III). Velayetin kaldırılması halinde, ana babanın çocuklarının bakım ve eğitim giderlerini karşılama yükümlülükleri devam eder (TMK 350). Öte yandan ana babanın, çocukla uygun kişisel ilişki kurulmasını isteme hakkı mevcuttur $(\text { TMK } 323,324)^{146}$. Doktrinde velayetin kaldırılması halinde, ana babadan alınan çocuğun evlatlık olarak verilmesi esnasında, kanunda öngörülen istisnaların dışında, ana babanın rızasının aranması gereğine işaret edilmektedir ${ }^{147}$.

Velayetin kaldırılmasını gerektiren sebep ortadan kalktığı takdirde hakim, re'sen ya da ana veya babanın istemi üzerine velayeti geri verir (TMK 351/II).

\footnotetext{
${ }^{139}$ Krş., Hegnauer, N 27.46; ayrıca bkz., BSK ZGB I-Breitschmid, Art.311/312 N 3, N 5, N 6vd. ; Öztan, s.643vd.

${ }^{140}$ Krş., Hegnauer, N 27.46; BSK ZGB I-Breitschmid, Art.311/312 N 7; ayrıca Tino Jorio, Der Inhaber der elterlichen Gewalt nach dem neuen Kindesrecht, Zürich 1977, s.329vd.; Öztan , s.643.

${ }_{141}$ Öztan, s.643; Akıntürk, s.433vd.; krş., Tuor/Schnyder/Rumo-Jungo, s.454.

${ }^{142}$ Krş., Hegnauer, N 27.46; ayrıca BSK ZGB I-Breitschmid, Art.311/312 N 8.

${ }^{143}$ Bkz., Öztan, s.644vd.; Akıntürk, s.434.

144 Öztan, s.645; Hegnauer, N 27.46; Stettler, s.517; BSK ZGB I-Breitschmid, Art.311/312 N 8.

${ }^{145}$ Krș., Hegnauer, N 27.46.

${ }^{146}$ Krş., Hegnauer, N 27.48; BSK ZGB I-Breitschmid, Art.311/312 N 1; Öztan, s.641.

${ }^{147}$ Hegnauer, N 27.48; BSK ZGB I-Breitschmid, Art.311/312 N 1. Ayrica bu hususta bkz. ve krş., Art.265a, 265c ZGB; TMK 309, 311.
} 


\section{Türk Medeni Kanunu'nun 24 ve 25. Maddelerine Göre Kișilik Hakkını Koruyan Davalarla Çocuğun Kişiliğinin Korunması}

a. Türk Medeni Kanunu'nun 24 ve 25. Maddelerinin Ana Baba ve Çocuk Arasındaki İlişkiye Uygulanabilirliği

\section{aa. Genel Olarak}

Türk Medeni Kanunu'nun kişiliğin hukuka aykırı saldırılardan korunmasına yönelik 24 ve 25 . maddelerinin ana baba ve çocuk arasındaki ilişkiye uygulanabilirliği meselesi, iki bakımdan değerlendirilebilir:

Öncelikle TMK 24 hükmünün defansif niteliği üzerinde durmak gerekir ${ }^{148}$; daha önce kişilik hakkına ilişkin olarak da belirtildiği gibi, bu hükümle kişilik hakkı saldırıya uğrayan kişiye, hakimden saldırıda bulunanlara karşı korunmasını istemek suretiyle esasen kendini savunma imkanı sağlanmaktadır. Bu itibarla çocuğun ana babadan kişiliğine saygı gösterilmesi yönünde bazı davranışlarda bulunmasına ilişkin olumlu talepleri, ancak velayeti düzenleyen hükümler çerçevesinde ve çocuğu koruyucu önlemler vasıtasıyla gerçekleștirilebilir. Su halde mesela; doktrinde $^{149}$ de belirtildiği üzere, özellikle çocuğun kişiliğine sayg1 gösterilmesi gereğini somutlaştıran TMK 339 ve 340 hükümleri uyarınca çocuğa olgunluğu ölçüsünde hayatını düzenleme serbestisinin tanınması, önemli konularda olabildiğince görüşünün alınması veya çocuğun bedensel, zihinsel, ruhsal, ahlaki ve toplumsal gelişiminin desteklenmesi ya da onun yeteneklerine ve eğilimlerine uygun düșecek genel ve mesleki bir eğitimin sağlanması gibi taleplerin gerçekleştirilmesi, yine bu hükümlere dayanılarak ve gerekirse çocuğu koruyucu önlemlere (Bkz., TMK 346 vd.) başvurmak suretiyle mümkün olabilir.

TMK 24 ve 25 hükümlerinin ana baba ve çocuk arasındaki ilişkiye uygulanabilirliğinde üzerinde durulması gereken diğer husus ise ana babanın çocuğun kişiliğine müdahale hakkıdır ${ }^{150}$. Bu husus, anılan hükümlere göre kişiliğin korunmasının şartı olarak kişiliğe yönelik müdahalenin ne zaman hukuka aykırı saldırı sayılacağının tespiti bakımından önemlidir. Daha önce de ifade edildiği üzere, kișilik hakkının mutlak niteliği dolayısıyla kișilik hakkına yönelik her müdahale, ilke olarak hukuka aykırıdır; ancak hukuka uygunluk sebeplerinin bulunması halinde müdahalenin hukuka aykırılığından söz edilemez. TMK 24/II hükmünde hukuka uygunluk sebepleri olarak kişilik hakkı zedelenen kişinin rızası, daha üstün nitelikte özel veya kamusal yarar ya da kanunun verdiği yetkinin kullanılması hallerine yer verilmiştir.

\footnotetext{
${ }^{148} \mathrm{Bu}$ hususta bkz. ve krş., Tschümperlin, s.104; Bucher, N 459; Hausheer/Aebi-Müller, Rz 10.11 .

${ }^{149}$ Krş., Tschümperlin, s.104, 142.

${ }^{150} \mathrm{Kr}$.̧., Tschümperlin, s.109vd.
} 
Ana baba, TMK 339 vd. hükümlerinde düzenlenen velayet hakkı kapsamında çocuğu eğitme ve ona talimat verme hakkına da sahiptiir ${ }^{151}$. Şu halde ana baba, velayet hakkına dayanarak çocuğa yönelik bazı müdahalelerde bulunabilecektir ${ }^{152}$. Bu noktada ana babanın velayet hakkından doğan yetkilerini kullanması, TMK 24/II hükmü anlamında kanunun verdiği bir yetkinin kullanılmasıdır ve buna göre hukuka uygunluk sebebi teşkil eder. Burada özel hukuktan kaynaklanan bir yetkinin kullanılması söz konusu olmaktadır ${ }^{153}$. Ancak ana babanın velayetten kaynaklanan müdahale hakkı sınırsız değildir. Ana babanın çocuğun kișiliğine yönelik müdahalesi, velayetin amacına uygun ve gereği gibi ifası için zorunlu olanı aşamaz ${ }^{154}$. Bu çerçevede ana baba, ölçülülük ilkesinin gereklerine göre hareket etmelidir ${ }^{155}$. Buna göre çocuğun kişiliğine yönelik müdahale, velayetin amacı bakımından elverişli, zorunlu ve makul (oranlı) olduğu takdirde hukuka uygundur.

TMK 24 ve 25 hükümlerinin ana baba ve çocuk arasındaki ilişkiye uygulanabilirliği, yukarıdaki açıklamalar çerçevesinde aşağıda çocuğun münferit kişilik değerleri bakımından ele alınacaktır.

\section{bb. Münferit Kişilik Değerleri Bakımından}

\section{aaa. Fiziksel Kişilik Değerleri}

Çocuğun fiziksel kişilik değerleri olarak, daha önce de belirtildiği gibi, her şeyden önce hayat hakkı ve vücut bütünlüğü (bedensel ve ruhsal sağllk) hakk1 anılmalıdır; öte yandan bu kategoriye çocuğun hareket özgürlüğü ve cinsel özgürlüğü de dahildir. Burada özellikle çocuğun vücut bütünlügüne ve hareket özgürlügüne yönelik müdahaleler üzerinde durulacaktır.

\section{Çocuğun Vücut Bütünlüğüne Yönelik Müdahaleler}

İsviçre doktrininde Tschümperlin'e göre çocuğun vücut bütünlüğü hakkı, ana babanın tedip hakkı ile bir dereceye kadar sınırlanmıştır ${ }^{156}$. Belirtmek gerekir ki İsviçre Medeni Kanunu'nda 1976 yılında yapılan revizyon ile ana babanın eğitim maksadıyla çocuğu tedip yetkisini öngören eski Art.278 hükmü, bu hususta başka bir düzenleme getirilmeksizin Kanun'dan çıkarılmıştır. Tschümperlin, anılan revizyon esnasında federal meclislerin tedibe ilişkin eski Art.278 hükmünün Kanun'dan çıarılmasını, ancak tedip hakkının velayetin içeriğinde yer alması şartıyla uygun bulduğunu ifade etmektedir ve bu sebepledir ki pratikte uzlaşılan görüşe

\footnotetext{
${ }^{151}$ Krş., Hausheer/Aebi-Müller, Rz 12.35.

${ }^{152}$ Krş., Tschümperlin, s.109; Rey, N 759; Schwenzer, OR AT, N 50.35.

${ }^{153}$ Krş., Hausheer/Aebi-Müller, Rz 12.35; Rey, N 759.

${ }^{154}$ Krş., Tschümperlin, s. 110.

${ }^{155}$ Krş., Serozan, N 247vd.

${ }^{156}$ Tschümperlin, s. 105.
} 
göre, 1976 revizyonu sonrasında da tedip hakkı, İsviçre hukuku bakımından velayetin içeriğinde bulunmaktadır ${ }^{157}$. Tedip hakk1, ana babanın çocuğun eğitimi için gerektiği takdirde onun hukuki varlıklarına, özellikle çocuğun vücut bütünlüğü, onuru, özgürlüğü gibi kişilik değerlerine müdahale oluşturabilen önlemlere başvurabilme yetkisini ifade eder; burada tedip önlemleri olarak genellikle çocuğu eğitsel açıdan istenilen davranışa yönlendirmek üzere çeșitli zorlama araçlarının (yaptırımların) kullanılması söz konusu olmaktadır ${ }^{158}$. Ancak tedip, doktrinde daha ziyade çocuğun vücut bütünlüğüne yönelik müdahaleleri kapsayan yönüyle tartışılmaktadır ${ }^{159} . \mathrm{Bu}$ noktada farklı yaklaşımlar söz konusudur.

Tedip kavramını öncelikle bedensel cezalandırma ve gerekirse bununla aynı etkiyi gösteren diğer her türlü sert cezalar için kullanmayı tercih eden Tschümperlin'e göre bedensel tedip, bazı hallerde çocuğun eğitimi için mutlak zorunlu olabilir ${ }^{160}$. Bununla birlikte çocuğun kişiliği bakımından olumsuz sonuçlara yol açması sebebiyle bedensel tedip, çok sık ve çok sert uygulanmamalıdır; bedensel tedibe ancak kaçınılmaz son çare olarak başvurulmalıdır. Bedensel tedip, sadece eğitsel değere sahip olduğu ve böylece çocuğun yararına hizmet ettiği yerde hukuken uygundur. Diğer taraftan bedensel tedip yoluyla hiçbir surette çocuğun sağlığı, bedensel, zihinsel veya ruhsal yararı tehlikeye düşürülemez; tedip sonucunda sadece çocuğun keyfini bozan, zararsız ve geçici ihlaller uygun görülebilir ${ }^{161}$.

Oftinger/Stark da yukarıda değinilen 1976 revizyonu ile ana babanın çocuğun eğitimi için gerekli ve zararsız önlemleri alma hakkının kaldırılmadığını ifade etmektedir ${ }^{162}$. Halihazırda Art.302/I ZGB (Krş., TMK 340/I) hükmünden kaynaklanan bu hak, çocuğun eğitimi ve bedensel tedibe dair zamanla değişen anlayışlara bağlıdır. Anılan yazarlar, bu çerçevede eskisi gibi ana babanın eğitim amacıyla çocuğun vücut bütünlüğüne müdahale hakkının bulunduğunu kabul etmektedir.

Hegnauer, velayetin gerekli ve uygun eğitim araçlarını kullanma yetkisini içerdiğini ifade etmektedir; buna karşllık çocuğun bedensel, zihinsel veya ruhsal bütünlüğünü ihlal eden ya da tehlikeye düşüren tedip araçları gayricaizdir ${ }^{163}$.

157 Tschümperlin, s.346; ayrıca Brauchli, s.203-204, 154, dn.385; BBl 1974 II 77; krş., BSK ZGB I-Schwenzer, Art.301 N 8.

${ }^{158}$ Krş., Joseph Kaufmann, Das Züchtigungsrecht der Eltern und Erzieher, Stuttgart 1910, s.13vd.; BK-Hegnauer, aArt.278 N 10vd.; Tschümperlin, s.347vd.

${ }^{159}$ Krş., Tschümperlin, s.345vd., 349vd.; BSK ZGB I-Schwenzer, Art.301 N 8; Kurt Affolter, Basler Kommentar zum Schweizerischen Privatrecht (Hrsg., Heinrich Honsell/Nedim Peter Vogt/Thomas Geiser), Zivilgesetzbuch I, Art.1-456, 2. Auflage, Basel 2002, Art.405 N 69vd.

160 Tschümperlin, s.357.

${ }^{161}$ Tschümperlin, s.348, 350, 351-352, 357.

${ }^{162}$ Karl Oftinger/Emil W. Stark, Schweizerisches Haftpflichtrecht, 2. Band: Besonderer Teil, 1. Teilband: Verschuldenshaftung, gewöhnliche Kausalhaftungen, Haftung aus Gewässerverschmutzung, 4. Auflage, Zürich 1987, N 232.

${ }^{163}$ Hegnauer, N 26.03 . 
Schwenzer ise bedensel tedibin karşısındadır. Schwenzer'e göre Art.301 ZGB (Krş., TMK 339) uyarınca ana babanın çocuğu eğitme hakkı, çocuğun özgürlüğüne yönelik bazı sınırlamaları haklı kılar, fakat bedensel tedip bunun dışındadır; çocuğun eğitiminde her türlü bedensel tedip gayricaiz görülmelidir ${ }^{164}$.

Ana babanın çocuğu tedip yetkisi, Yeni Medeni Kanun'daki düzenleme sebebiyle Türk hukuku bakımından da üzerinde durulması gereken bir husustur. Yeni Medeni Kanun, eski Medeni Kanunu'nun tedip hakkını öngören 267. maddesine yer vermemiştir. Eski Medeni Kanun'un 267. maddesi hükmü çerçevesinde tedip, ana babanın velayet hakkı kapsamında çocuğun eğitimi için gerekli araçları kullanabilme yetkisi olarak anlaşılmaktayd ${ }^{165}$. Bu noktada gerekli araçlar bağlamında çocuğa öğüt verilmesinden uyarıda bulunup, zorunlu hallerde cezalandirılmasına, hatta dayak vb. güç kullanılmasına kadar farklı ağırlıktaki önlemlere başvurma imkanı söz konusu olmaktaydd ${ }^{166}$. Ancak Türk hukuk doktrininde de tedip yetkisinin, ölçülülük ilkesine uygun olarak kullanılması gereği; tedip suretiyle çocuğun sağlığına zarar verilemeyeceği, vücut bütünlüğünün zedelenemeyeceği ve ruhsal gelişiminin engellenemeyeceği kabul edilmekteydi ${ }^{167}$. Öte yandan bu çerçevede tedip hakk1, Türk hukukunda özel hukuk kaynaklı bir yetkinin kullanılması bağlamında aynı zamanda bir hukuka uygunluk sebebi teşkil etmekteydi ${ }^{168}$. Buna göre ana babanın tedip hakkını kullanırken, çocuğun kişisel özgürlük veya vücut bütünlüğüne verebilecekleri makul ölçüdeki ihlaller, hukuka aykırılık oluşturmamaktaydı.

Yeni Medeni Kanun'da tedip kavramına neden yer verilmediğine ilişkin olarak Kanun'un gerekçesinde açıklık bulunmadığ 1 gibi, bu suretle tedip hakkının maddi hukuk anlamında kaldırılmış olup olmadığı hususu da açık değildir ${ }^{169}$. Kanımızca bu husus, çocuğun eğitiminde başvurulacak araçların hangilerinin hukuken ve çocuğun yararı bakımından kabul edilebilir olduğu meselesi ile birlikte ve tedip kavramına yüklenen anlam bağlamında ele alınmalıdır. Ancak bu, ayrı bir incelemenin konusudur. Yine de bu noktada

\footnotetext{
${ }^{164}$ BSK ZGB I-Schwenzer, Art.301 N 8; OR AT, N 50.35.

${ }^{165} \mathrm{Bu}$ hususa ilişkin olarak Türk hukukunda bkz., İnan, s.130vd.; Köprülü/Kaneti, s.249; Oğuzman/Dural, s.281; Bilge Öztan, Aile Hukuku, 3. Bası, Ankara 2000, s.503; Akıntürk, s.408.

${ }^{166}$ Hifzı Veldet Velidedeoğlu, Türk Medeni Hukuku, Cilt II, Aile Hukuku, İstanbul 1965, s.372; İnan, s.131; Feyzi Necmeddin Feyzioğlu, Aile Hukuku, 3. Bas1 (Bu basıy hazırlayanlar: Cumhur Özakman/Enis Sarıal),İstanbul 1986, s.512; Köprülü/Kaneti, s.249; Selahattin Sulhi Tekinay, Türk Aile Hukuku, 7. Bas1, İstanbul 1990, s.490; Oğuzman/Dural, s.281; Öztan (2000), s.503; Serozan, N 251; Zevkliler/Acabey/Gökyayla, s.1018; Akıntürk, s.408.

${ }^{167}$ Bkz., dn.166.

${ }^{168}$ Fikret Eren, Borçlar Hukuku, Genel Hükümler, Cilt I, 6. Bası, İstanbul 1998, s.586; M. Kemal Oğuzman/M. Turgut Öz, Borçlar Hukuku, Genel Hükümler, 2. Bası, İstanbul 1998, s.486; Öztan, Şahsın Hukuku, s.150.

${ }^{169}$ Bkz., Yeni Medeni Kanun'un gerekçesi (Dn.128), s.126vd.
} 
ifade edilmesi gereken şudur ki; bugün çocuğa şiddetten uzak bir ortamda büyüme ve eğitim alma hakkını tanıyan ve bunu uluslararası belgelere de derceden bir anlayışın hüküm sürdüğü safhada ${ }^{170}$, tedip hakkına dayanılarak ana babanın çocuğun vücut bütünlüğüne yönelik müdahale yetkisi kabul edilmemelidir. Burada makul ölçünün sınırının belirlenmesi çok güçtür ve keyfiliğe sebebiyet verebilir. Bize göre tedip yoluyla çocuğun vücut bütünlüğü (bedensel ve ruhsal sağlık) hakkına müdahale edilmemelidir.

Çocuğun vücut bütünlüğü hakkına ilişkin olarak ele alınması gereken bir diğer konu ise çocuğa yönelik tıbbi müdahalelerdir. Tıbbi müdahaleye rıza gösterilmesinde kişiye sıkı sıkıya bağlı bir hakkın kullanılması söz konusudur; bununla birlikte ayırt etme gücüne sahip çocuğun tıbbi müdahaleye tek başına rıza gösterip gösteremeyeceği doktrinde tartışmalıdır ${ }^{171}$. Burada belirtmek istediğimiz husus şudur; çocuğun tıbbi müdahaleye tek başına rıza göstermesinin yeterli olduğunu savunan görüş çerçevesinde de çocuğun tedaviyi reddettiği bazı hallerde, özellikle çocuğun hayatının devamı veya sağlığının korunması için tıbbi müdahalenin kaçınılmaz olduğu durumlarda ana babanın velayet hakkından kaynaklanan bakım ve gözetim ödevine dayanarak çocuğun kararının önüne geçebileceği ifade edilmektedir ${ }^{172}$. Çocuğun ayırt etme gücünün bulunmaması halinde ise tıbbi müdahaleye ana babanın rizası aranacaktır ${ }^{173}$. Ancak bu halde de ana babanın aşamayacağı kesin sınırlar mevcuttur. Hukuk düzenlerinin, ana babanın rızası bulunsa dahi bazı tıbbi müdahalelerin küçüklere uygulanmasını yasakladığı hallerde, durum böyledir ${ }^{174}$.

\footnotetext{
${ }^{170}$ Bu noktada Çocuk Haklarına Dair Sözleşme'nin (Dn.57) 19. maddesi hükmü anılmalıdır. Anılan hükmün ilk fikrasına göre: "Bu Sözleşmeye Taraf Devletler, çocuğun ana babasının ya da onlardan yalnızca birinin, yasal vasi veya vasilerinin ya da bakımını üstlenen herhangi bir kişinin yanında iken bedensel veya zihinsel saldırı, şiddet veya suistimale, ihmal ya da ihmalkâr muameleye, ırza geçme dahil her türlü istismar ve kötü muameleye karşı korunması için; yasal, idari, toplumsal, eğitsel bütün önlemleri alırlar”. Alman Medeni Kanunu'nda çocuğun şiddetten uzak bir eğitim hakkına sahip olduğu açıkça hükme bağlanmıştır (§ 1631 II BGB).

${ }^{171}$ Ayırt etme gücüne sahip küçüğe yapılacak tıbbi müdahaleye rıza konusunda doktrindeki tartışmalar ve Türk hukukundaki düzenleme için bkz., Zarife Şenocak, "Küçüğün Tıbbi Müdahaleye Rizası”, Ankara Üniversitesi Hukuk Fakültesi Dergisi, Cilt 50, Say1 4 (2001), s.74vd.; ayrıca Max Nägeli, Die ärztliche Behandlung handlungsunfähiger Patienten aus zivilrechtlicher Sicht, Zürich 1984, s.123vd.

${ }^{172}$ Bkz., mesela Tschümperlin, s.110-111, 242.

173 Tschümperlin, s.239; Näf-Hofmann, s.90;Bucher, N 528; Margrith Bigler-Eggenberger, Basler Kommentar zum Schweizerischen Privatrecht (Hrsg., Heinrich Honsell/Nedim Peter Vogt/Thomas Geiser), Zivilgesetzbuch I, Art.1-456, 2. Auflage, Basel 2002, Art.19 N 41; Şenocak, s.73.

${ }^{174}$ Bu hususta Türk hukukunda bkz., örneğin, TMK 40; 2238 sayılı Organ ve Doku Alınmas1, Saklanması ve Nakli Hakkında Kanun, m.5; 2827 sayılı Nüfus Planlaması Hakkında Kanun, m.4.
} 


\section{Çocuğun Hareket Özgürlüğüne Yönelik Müdahaleler}

Doktrinde çocuğun hareket özgürlüğünün ana babayla birlikte evde yaşama yükümü ile sınırlanmış olduğu ifade edilmektedir ${ }^{175}$. Gerçekten TMK 339/IV (Art.301 Abs.3 ZGB) hükmüne göre "çocuk, ana ve babasının rızası dışında evi terkedemez ve yasal sebep olmaksızın onlardan alınamaz". Esasen bu hükümle aynı zamanda ana babanın velayet hakkı çerçevesinde çocuğun kalacağ 1 yeri belirleme ve bu suretle onun bakımı ve eğitimi ile doğrudan ilgilenme hakkına işaret edilmiş bulunmaktadır ${ }^{176}$. Çocuk, kalacağ yere ilisskin olarak ana babanın talimatlarına uymak zorundadır (Krş., TMK 339/II) ${ }^{177}$. Çocuğun ana babanın bu husustaki talimatlarına aykırı davranması halinde ise çocuğa karșı zor kullanılmamalıdır ${ }^{178}$; bununla birlikte doktrinde özellikle ayırt etme gücü bulunmayan çocuğa karşı zor kullanılabileceği ileri sürülmektedir ${ }^{179}$. Ana baba, çocuğun kalacağ 1 yeri belirlerken olgunluğu ölçüsünde çocuğun iradesini de göz önünde bulundurmalıdır (Bkz., TMK 339/III) ${ }^{180}$.

Öte yandan ana babanın, çocuğu eğitsel açıdan hedeflenen davranışa yönlendirmede gerekli gördükleri takdirde çocuğun kişisel özgürlügüne yönelik bazı yaptırımlara başvurmaları söz konusu olabilmektedir ${ }^{91}$. Böyle bir yaptırımın hukuken haklı kabul edilebilmesi için ölçülülük ilkesinin gereklerinin yerine getirilmesi aranır ${ }^{182}$. Buna göre çocuğun kişisel özgürlüğüne yönelik müdahale, eğitsel açıdan elverişli, zorunlu ve izlenen amaçla oranlı olmalıdır. Bu bağlamda doktrinde mesela ev ya da oda hapsi anlamında kısa süreli özgürlüğü bağlayan yaptırımlar uygun bulunurken, çocuğa sürekli dışarı çıkma yasağı getirilmesi uygun bulunmamaktadır ${ }^{183}$.

\section{bbb. Duygusal Kişilik Değerleri}

TMK 24 hükmü çerçevesinde korunan kişilik değerleri arasında kişinin duygu hayatı (ruhsal-duygusal hayat alanı) da yer alır. Doktrinde hukuken

\footnotetext{
175 Tschümperlin, s.105; krş., Schwenzer, OR AT, N 50.35.

${ }^{176}$ Krş., BSK ZGB I-Schwenzer, Art.301 N 9vd.; Tschümperlin, s.149vd., 154, 37; Frank, "Grenzbereiche", s.37; Hegnauer, N 26.06vd.

${ }^{177}$ Krş., BSK ZGB I-Schwenzer, Art.301 N 13; Hegnauer, N 26.08; Tschümperlin, s.150-151, $153 \mathrm{vd}$.

${ }_{178}^{178}$ BSK ZGB I-Schwenzer, Art.301 N 13.

${ }^{179}$ Tschümperlin, s.189; ayrica bkz., BK-Hegnauer, aArt.273 N 87, N 90vd.

${ }^{180}$ BSK ZGB I-Schwenzer, Art.301 N 12; Tschümperlin, s.153, 179vd.; Hegnauer, N 26.06.

${ }^{181}$ Bu hususta bkz., Tschümperlin, s.352vd., 354; BSK ZGB I-Affolter, Art.405 N 68; BKHegnauer, aArt.278 N 12; Kaufmann, s.14, 152vd.

${ }_{182}$ Krş., Serozan, N 251; BK-Hegnauer, aArt.278 N 10, N 19vd.; Tschümperlin, s.350, 353; Kaufmann, 153vd.; BSK ZGB I-Affolter, Art.405 N 70.

${ }^{183}$ Tschümperlin, s.354; BK-Hegnauer, aArt.278 N 12; Kaufmann, s.154vd.; BSK ZGB IAffolter, Art.405 N 70.
} 
önemli bir ihlalin söz konusu olması için kişinin duygu hayatının doğrudan ve kalıcı bir biçimde zedelenmesi gerektiği ifade edilmektedir ${ }^{184}$.

Bazı hallerde kişinin vücut bütünlüğünün ihlali, duygusal bütünlüğün ihlaline de yol açabililir ${ }^{185}$. Bu bağlamda mesela ana babanın çocuğa yönelik dayak, tokat, şamar, tekme vb. bedensel müdahalelerinin, çocuğun duygu dünyasını tahrip etmesi, çocukta manevi acı, elem veya keder yaratması mümkündür. Böyle bir durumda şartların gerçekleşmesi halinde çocuğun uğradığı manevi zararın telafi edilmesi gerekir (Bkz., BK 47, 49) ${ }^{186}$.

Kişinin duygusal kişilik değerleri arasında özellikle kişinin ailesi ile ilişkileri üzerinde durmak gerekir. Kişi, ailevi ilişkilerinin üçüncü kişilerin müdahalelerine karşı korunmasını kişiliği koruyucu hükümler uyarınca talep edebilir. Doktrinde ana baba ve çocuk arasındaki duygusal ilişkiye, kişiliği koruyucu hükümlerin uygulanamayacağı veya ancak tali biçimde uygulanabileceği ifade edilmektedir ${ }^{187}$. Zira çocuğun ana babasıyla ilişkisinin devam ettirilmesi ya da korunması, öncelikle çocuğun korunmasına yönelik hükümler çerçevesinde (Bkz., TMK 346 vd.) veya çocukla kişisel ilişki kurulmasını düzenleyen hükümler (Bkz., TMK 323 vd.) vasıtasıyla gerçekleştirilir ${ }^{188}$.

\section{ccc. Sosyal Kişilik Değerleri}

Sosyal kişiliğin korunmasında kişinin toplumdaki hayatının çeşitli bakımlardan korunması söz konusu olmaktadır. Sosyal kişilik değerleri olarak özellikle kişinin sosyal çevresiyle ilişkileri, kişinin özel ve gizli hayat alanları, kişinin onuru anılabilir; keza kişinin adı ve ekonomik özgürlüğü de sosyal kişilik değerlerindendir ${ }^{189}$. Çocuğun sosyal kişilik değerleri bakımından burada çocuğun özel ve gizli hayat alanları, çocuğun üçüncü kişilerle ilişkileri ve çocuğun onuru üzerinde durulacaktır.

\section{İlişkileri}

Çocuğun Özel ve Gizli Hayat Alanlart - Çocuğun Üçüncü Kişilerle

Kişinin özel alanı, sadece belirli bir çevrenin (aile, akraba, arkadaş, tanıdık vb.) bilgisiyle sınırlı kişisel nitelikteki bütün olguları kapsar ${ }^{190}$.

\footnotetext{
${ }^{184}$ Hausheer/Aebi-Müller, Rz 12.68.

${ }^{185}$ Krş., Hausheer/Aebi-Müller, Rz 12.70-12.71; ayrıca bkz., Eren, s.754vd.

${ }^{186}$ Krş., Hausheer/Aebi-Müller, Rz 12.71.

${ }^{187}$ Tschümperlin, s.105-106; Bucher, N 471.

${ }^{188}$ Bucher, N 471; Hausheer/Aebi-Müller, Rz 12.83; Tschümperlin, s.106.

${ }^{189}$ Tschümperlin, s.106; Bucher, N 501vd., N 503vd.; krş., Hausheer/Aebi-Müller, Rz 12.41, Rz 12.86; BSK ZGB I-Meili, Art.28 N 17.

${ }^{190}$ Krş., Bucher, N 477; Pedrazzini/Oberholzer, s.137; Hausheer/Aebi-Müller, Rz 12.127; Dural/Öğ̈̈z, s.126; Öztan, Şahsın Hukuku, s.134.
} 
Üçüncü kişilerin bu alana hukuka aykırı biçimde, söz konusu kişisel olguları veya bilgileri öğrenmek, derleyip toplamak ya da özellikle başkalarına da yaymak kastıyla müdahale etmeleri halinde, özel alanın ve bu suretle kişiliğin ihlali gerçekleşmiş olur ${ }^{191}$. Kişinin gizlilik alanı ise kişinin sadece özellikle güvenerek kendilerine bildirdiğ $\mathrm{i}$ kişilerle paylaşmak istediği olgulardan oluşur ${ }^{192}$.

Doktrinde özel alana dahil olan aile fertlerinin ilişkisi ve bu suretle ana baba ve çocuk ilişkisi bakımından kişiliği koruyucu hükümlerin uygulanamayacağ 1 veya ancak tali biçimde uygulanabileceği ifade edilmektedir ${ }^{193}$. Zira bu halde ana baba, zaten özel alana dahildir ve özel alan kapsamındaki olgulardan zorunlu olarak bilgi sahibidir. Cocuğun özel alanı, ancak çocuğun ana babasının dışında, arkadaş vb. diğer kendisine yakın üçüncü kişilerle ilişkileri söz konusu olduğu takdirde, ana babaya karşı korunabilir ${ }^{194}$. Bununla birlikte çocuğun üçüncü kişilerle ilişkileri bakımından da ana babanın velayetten kaynaklanan genel müdahale hakkı saklıdır ${ }^{195}$.

Bu noktada ana babanın çocuğun üçüncü kişilerle ilişkilerine müdahale hakk1 üzerinde durmak gerekir (Krş., TMK 326/III) ${ }^{196}$. Ana baba, çocuğun üçüncü kişilerle ilişkilerine müdahale hakkını, ölçülülük ilkesinin gereklerine uygun kullanmalıdır ${ }^{197}$. Özellikle çocuğun ayırt etme gücünün bulunması halinde ana baba, olgunluğu ölçüsünde çocuğa çevresiyle temas imkanını vermelidir (Bkz., TMK 339/III) ${ }^{198}$. Esasen velayetin nihai amacının gerçekleştirilebilmesi, bunu gerektirir. Diğer bir ifadeyle çocuğun bağımsız bir kişi olarak topluma uyum ehliyetini kazanabilmesi için özellikle yaşıtı üçüncü kişilere yönelmeye, onlarla ilişki kurmaya ihtiyacı vardır ${ }^{199}$. Bu husustaki bir yasak, ancak hakl1 sebeplerin bulunması halinde çocuğun korunması amacıyla uygun görülebilir (Mesela çocuğun yaşça kendisinden büyük, kötü şöhretli bir kişiyle arkadaşlık yapması halinde olduğu gibi) ${ }^{200}$.

Doktrinde tartışmasız kabul edilen görüşe göre ayırt etme gücü bulunan çocuk, ilke olarak gizlilik alanının ana baba karşısında korunmasına yönelik talep hakkına sahiptir ${ }^{201}$. Zira bir olgunun sır olarak gizli tutulması için sır

\footnotetext{
${ }^{191}$ Bucher, N 477, N 479; Hausheer/Aebi-Müller, Rz 12.134vd.

192 Bucher, N 480; Hausheer/Aebi-Müller, Rz 12.124; Pedrazzini/Oberholzer, s.137; Dural/Öğüz, s.126; Öztan, Şahsın Hukuku, s.134.

${ }^{193}$ Tschümperlin, s.107.

194 Tschümperlin, s.107.

195 Tschümperlin, s. 107.

${ }^{196}$ Bu hususta bkz., Tschümperlin, s.245; BSK ZGB I-Schwenzer, Art.301 N 11; Hegnauer, N 26.06; BK-Hegnauer, aArt.273 N 106vd.; ZK-Egger, aArt.275 N 5.

${ }^{197}$ Serozan, N 249.

${ }^{198}$ Tschümperlin, s.246.

199 Tschümperlin, s.245.

${ }^{200}$ Tschümperlin, s.247; ayrıca BK-Hegnauer, aArt.273 N 106, N 108.

${ }^{201}$ Tschümperlin, s.107, 229vd.; Frank, N 401; Frank, "Grenzbereiche", s.45; BK-Hegnauer,
} 
sahibinin bu hususta üçüncü kişilerce anlaşılabilir bir menfaatinin ve iradesinin bulunması gerekir ${ }^{202}$. Ayırt etme gücüne sahip çocuk, bir olgunun sır olarak gizli tutulup tutulmayacağı hususunda iradesini oluşturabilecek durumdadır. Esasen çocuk, ayırt etme gücü ölçüsünde gizlilik alanına sahip olur ${ }^{203}$.

Çocuğun gizlilik alanı bakımından özellikle mektup ve yazılarına ilişkin sırları ile sağlık ilişkileri üzerinde durmak gerekir. Doktrinde ana babanın velayet yetkisine dayanarak prensipte çocuğun mektup yazışmasını kontrol hakkına sahip olduğu kabul edilmektedir ${ }^{204}$. Ancak burada mesele, ana babanın söz konusu kontrol hakkını hangi ölçüde kullanması gerektiğidir. Ana babanın ayırt etme gücüne sahip çocuğun iradesine karş1 veya çocuğun iradesi bulunmaksızın çocuğun mektup yazışmasına müdahale edebilmesinin kriterleri, doktrinde farklılık göstermektedir ${ }^{205}$. Bununla birlikte esas olması gereken şudur ki ana baba, velayet görevinin gerektirdiği ölçüde çocuğun mektuplarını kontrol edebilir ${ }^{206}$. Burada çocuğun mektup yazışmasının gizli tutulmasındaki haklı menfaatleri ile ana babanın velayetten doğan yükümlerini ifa edebilmesinin gerekleri arasında bir değerlendirme yapılmalıdır; diğer bir ifadeyle karşılıklı menfaatlerin tartılması yönüne gidilmelidir ${ }^{207}$.

Çocuğun mektup yazışmasına ilke olarak ana baba tarafindan da saygı gösterilmelidir; bunda çocuğun korunmaya değer bir menfaati olduğu tereddütsüz kabul edilmelidir ${ }^{208}$. Esasen çocuğun kişiliğinin sağl1klı gelişebilmesi ve çocuğun ileride başkalarının kişiliğine de saygı gösterebilmesi, çocuğun gizlilik alanının ana babanın haksız müdahalelerinden korunmasını gerektirir. Belirli bir bağımsızlı̆̆ elde eden çocuğun rızası alınmadan gizlilik alanına yönelik müdahalenin, çocuk tarafindan güvenin zedelenmesi olarak algilanması mümkündür ${ }^{209}$. Bu bağlamda haklı sebeplerle kesinlikle kaçınılmaz nitelikteki istisnai müdahalelerin dışında çocuğun gizlilik alanı ana baba karşısında da korunmalıdır ${ }^{210}$. Ana baba, olgunluğu ölçüsünde çocuğa hayatını düzenleme imkanını, bu alanda da tanımak zorundadır (Bkz., TMK 339/III) ${ }^{211}$.

aArt.273 N 22.

${ }^{202}$ Hausheer/Aebi-Müller, Rz 12.125; Bucher, N 480; Dural/Öğüz, s.126.

${ }^{203}$ Krş., Tschümperlin, s.229.

204 Tschümperlin, s.230; BK-Hegnauer, aArt.273 N 109; Hegnauer, N 26.06; ZK-Egger, aArt.275 N 5.

${ }^{205} \mathrm{Bu}$ hususta ayrıntılı bilgi için bkz., Tschümperlin, s.231.

${ }^{206}$ Tschümperlin, s.231.

${ }^{207}$ Tschümperlin, s.231-232.

${ }^{208}$ Tschümperlin, s.232.

${ }^{209}$ Tschümperlin, s.232.

${ }^{210}$ Krş., Tschümperlin, s.232; Serozan, N 249.

211 Tschümperlin, s.232. 
Aynı esas, çocuğun günlük, hatıra defteri gibi yazıları bakımından da geçerlidir $^{212}$.

Çocuğun gizlilik alanı bakımından üzerinde durulması gereken diğer önemli mesele de çocuğun sağlık ilişkileridir. Ayırt etme gücü bulunan çocuğun kendisini tedavi eden hekimin bu vesileyle öğrendiği bilgileri, diğer bir deyimle meslek sırrını ana baba karşısında da gizli tutmasına yönelik bir talebinin olup olmadığı ve böyle bir talebin kabul edilmesi halinde ne ölçüde olduğu literatürde tartışmalıdır ${ }^{213}$. Bununla birlikte ayırt etme gücüne sahip çocuğa, ilke olarak kendisini tedavi eden hekimin meslek sırrını ana baba karşısında da gizli tutmasına yönelik bir talep hakkının tanınması yönünde bir eğilimin bulunduğu gözlemlenmektedir ${ }^{214}$. Özellikle cocuğun tedavi sözleşmesini tek başına yapabileceğinin savunulduğu bazı hallerde (mesela tedavi masraflarının ana babanın olağan nafaka yükümünü aşmadığı veya çocuğun kişisel kazancından ya da serbest mallarından karşılandığ 1 durumlarda $)^{215}$, bu eğilim açıktır. Burada bir yandan hastanın gizlilik alanı, diğer yandan da hekimle hasta arasındaki güven ilişkisi göz önünde tutulmalıdır. Çocuk, kendisini tedavi eden hekime hiçbir şeyden çekinmeden güvenmelidir; esasen çoğu kez çocuk, hekimin tedavi sırasında öğrendiği bilgileri hiç kimseye, bu arada ana babaya da açıklamayacağına güvenerek hekim seçimini yapmıştır ${ }^{216}$. Gerçi bu halde de hekimin meslek sırrı, çocuğun sağlık durumunun gerekli kıldığı bazı hallerde açıklanabilirr ${ }^{217}$. Mesela çocuğun hastalıktan iyileşme sürecinin hızlandırılması veya başka tehlikelerin bertaraf edilebilmesi için özel koruma, tıbbi uygulama vb. önlemlerin gerekli olması halinde, ana babanın çocuğun durumundan haberdar edilmesi uygun görülebilir. Öte yandan çocuk da sirlarının açıklanmasına rıza gösterebiliri ${ }^{218}$.

Çocuğun hekime bizzat başvurduğu hallerden farklı olarak, ana babanın hekimi çağırarak onunla tedavi sözleşmesini yaptığ 1 ve özellikle tedavinin önemli mali sonuçlara yol açmasının beklendiği yerde, ana babanın çocuğun sağl1k durumu hakkında aydınlatılmasında menfaatinin bulunduğu kesin görünmektedir ${ }^{219}$. Burada aksi yöndeki görüşlerle birlikte ana babanın aydınlatılmasının, tedavi sözleşmesinin kurulması, devamı veya sona erdirilmesi bakımından gerekli olanla sinırlı tutulması savunulmaktadır ${ }^{220}$. Ancak burada da çocuğun hekimi ana babanın hiçbir şekilde

${ }^{212}$ Tschümperlin, s.232-233; ayrıca bkz., Serozan, N 249.

${ }^{213}$ Bu hususta bkz., Tschümperlin, s.235; Frank, N 405; Nägeli, s.120.

${ }^{214}$ Tschümperlin, s.235; ayrıca bkz., Frank, N 407vd.

${ }^{215}$ Bu hususta bkz., Nägeli, s.120, 86vd.; Tschümperlin, s.236, dn.178, 240vd.; Frank, N 430.

${ }^{216}$ Tschümperlin, s.235.

217 Krş., Tschümperlin, s.235-236; Frank, "Grenzbereiche”, s.46; Frank, N 407; BKHegnauer, aArt.273 N 30a.

${ }^{218}$ Frank, N 410; Tschümperlin, s.237.

${ }^{219}$ Nägeli, s.121.

${ }^{220}$ Nägeli, s.121; krş., BK-Hegnauer, aArt.273 N 30a. 
bilgilendirilmemesi hususunda uyarması halinde, hekim buna uymalıdır ${ }^{221}$. Öte yandan çocuğun tıbbi müdahaleye rıza ehliyetine ilişkin olarak somut halde belirsizlik hakimse, tıbbi müdahalede bulunabilmek için hem çocuğun hem de ana babanın rızası alınmalıdır; bu durumda gerek çocuk gerek ana baba aynı kapsamda aydınlatılmalıdır ${ }^{222}$. Türk hukukunda hastanın küçük olması halinde, tıbbi müdahalede bulunabilmek için velisinden veya vasisinden izin alınması öngörülmüştür ${ }^{223}$. Şu halde Türk hukukundaki düzenleme uyarınca çocuğa uygulanacak tıbbi müdahale hakkında ana babanın bilgilendirilip aydınlatılması gereklidir. Bununla birlikte çocuğun sağlık durumu hakkında ana babaya bilgi verilmesinin çocuğun yararını tehlikeye düşürebileceği veya tedavi sürecini olumsuz etkileyebileceği hallerde hekimin ana babayı aydınlatmadan kaçınabileceği kabul edilmelidir.

Çocuğun, sırlarıyla ilgili olarak kendisini tedavi eden hekimin ana baba karşısında da susmasındaki haklı menfaati, prensipte ana babanın velayetten kaynaklanan menfaatlerinden önce gelir ${ }^{224}$. Bununla birlikte doktrinde ana babanın çocuğa ilişkin bakım ve gözetim ödevinin, gereğinde çocuğun sırlarının açıklanmamasına yönelik hakkını sınırlayabileceği de ifade edilmektedir ${ }^{225}$.

\section{Çocuğun Onuru}

Onur, hukuki anlamda kişinin özsaygısını ve yaşadığı toplum tarafından gerekli sayılan moral niteliklere sahip olduğu veya öyle zannedildiği için gördüğü saygıyı ifade eder ${ }^{226}$. Kişiliği koruyucu hükümler çerçevesinde kişinin ahlaki saygınlığı ile birlikte mesleki, ekonomik ve toplumsal saygınlığının da korunması söz konusu olmaktadır ${ }^{227}$. Kişi hakkında gerçek olmayan olguların ileri sürülmesi veya kişiyi uygunsuz biçimde gereksiz yere incitici değer yargıları, kişinin onurunun ihlaline yol $\operatorname{açar}^{228}$.

Bağımsız kişiliğiyle çocuk da onurunun korunmasına yönelik talep hakkına sahiptir ${ }^{229}$. Ana baba, çocuğun onuruna saygı göstermelidir. Bu

\footnotetext{
${ }^{221}$ Nägeli, s.121; ayrıca bkz., Frank, N 407.

${ }^{222}$ Nägeli, s.121.

${ }^{223}$ Bkz., 1219 sayılı Tababet ve Şuabatı San'atlarının Tarzı İcrasına Dair Kanun, m.70; Hasta Hakları Yönetmeliği (RG.01.08.1998, S.23420), m.24, 26.

${ }^{224}$ Tschümperlin, s.235.

${ }^{225}$ Frank, "Grenzbereiche", s.46; Frank, N 404; ayrıca bkz., BK-Hegnauer, aArt.273 N 30a.

226 Tschümperlin, s.108; Pedrazzini/Oberholzer, s.135; Hausheer/Aebi-Müller, Rz 12.88; Bucher, N 492; Dural/Öğüz, s.118; Oğuzman/Seliçi/Oktay, s.124; Özsunay, s.116vd.; Öztan, Şahsin Hukuku, s.128vd.

227 Bucher, N 492; BSK ZGB I-Meili, Art.28 N 28; Pedrazzini/Oberholzer, s.135; Dural/Öğüz, s.118; Oğuzman/Seliçi/Oktay, s.125; Öztan, Şahsın Hukuku, s.128.

${ }^{228}$ Hausheer/Aebi-Müller, Rz 12.110vd.; Pedrazzini/Oberholzer, s.136-137; Öztan, Şahsın Hukuku, s.129vd.; Oğuzman/Seliçi/Oktay, s.125; Dural/Öğüz, s.119; Özsunay, s.117.

${ }^{229}$ Tschümperlin, s. 108.
} 
noktada çocuğun eğitiminde her türlü onur kırıcı önlemin hukuken kabul edilemez olduğu vurgulanmalıdır ${ }^{230}$.

\section{b. Çocuğun Dava Hakkı}

Ayırt etme gücüne sahip çocuk, kişilik hakkının ana babanın hukuka aykırı müdahalesi ile ihlal edilmesi veya ihlal tehlikesine maruz kalması halinde TMK 24 ve 25 hükümleri uyarınca hakimden korunmasını isteyebilir $^{231}$. Doktrinde kişiliğin korunmasına yönelik savunma taleplerinin (saldırının önlenmesi, saldırının durdurulması ve saldırının hukuka aykırılığının tespiti davalarının) ve manevi tazminat talebinin ileriye sürülmesinin kişiye sıkı sıkıya bağlı hakkın kullanılması niteliğinde olduğu kabul edilmektedir; bu sebeple söz konusu taleplerin ayırt etme gücünün bulunması halinde çocuk tarafindan tek başına ileri sürülmesi mümkündür (Bkz., TMK 16/I; Art.19 Abs.2 ZGB) ${ }^{232} 233$. Buna karşıllk kişiliğin ihlalinden doğan maddi tazminat talebinin ileri sürülebilmesi için çocuğun kanuni temsilcisinin de rızası gerekir ${ }^{234}$. Ancak burada çocuğun maddi tazminat talebinin bizzat kanuni temsilciye karşı ileri sürülmesi söz konusu olmaktadır. Diğer bir ifadeyle burada kanuni temsilci durumundaki ana baba ile çocuk, davanın tarafları olarak ortaya çıkmaktadır. Böyle bir halde TMK 426/b.2 anlamında kanuni temsilcinin menfaati ile küçügün menfaatinin çatışması söz konusu olup, çocuğa bir temsil kayyımının atanması gerekir ${ }^{235}$.

Öte yandan çocuğun ayırt etme gücünün bulunmaması halinde de çocuğa kişiliğin korunmasına yönelik savunma ve tazminat taleplerini ileri sürebilme imkanı sağlanmalıdır. Doktrinde çocuğun ayırt etme gücüne sahip olmaması halinde, kişiliği koruyucu davaların çocuk adına kanuni temsilcisi

${ }^{230}$ BSK ZGB I-Schwenzer, Art.301 N 8; Serozan, N 251; İnan, s.131.

${ }^{231}$ Krş., Tschümperlin, s.111.

${ }^{232}$ Bu hususta bkz., BK-Bucher, Art.19 N 222vd., N 225; Tschümperlin, s.128vd.; krş., BSK ZGB I- Bigler-Eggenberger, Art.19 N 41; manevi tazminat talebine ilişkin olarak farklı görüş Eren, s.754.

${ }^{233}$ Doktrinde çocuğun dava masrafları dolayısıyla kişiliği koruyucu davaları tek başına açıp açamayacağı hususunda farklı görüşler bulunmaktadır. Bir görüşe göre dava masrafları, çocuğun serbest mallarından karşılanmadığı sürece kişiye sıkı sıkıya bağlı hakların dava yoluyla ileri sürülmesi, ana babanın rızasını gerektirir (Bkz., BK-Hegnauer, aArt.279 N 7576; Frank, N 381). Buna karşılık Bucher'e göre dava masrafları rizikosu, ayırt etme gücüne sahip küçüğün kişiye sıkı sıkıya bağlı haklarını tek başına kullanabileceği kuralını sınırlamamalıdır. Kişiye sıkı sıkıya bağlı hakların ayırt etme gücüne sahip küçük tarafından tek başına kullanılabilmesi, bunların dava yoluyla ileri sürülebilmesini de içerir (BK-Bucher, Art.19 N 197). Ayrıca bu hususta bkz., Tschümperlin, s.114vd.; Nägeli, s.26.

${ }^{234}$ Krș., BK-Bucher, Art.19 N 227; Tschümperlin, s.128-129.

${ }^{235} \mathrm{Bu}$ hususta bkz. ve krş., BSK ZGB I-Schwenzer, Art.306 N 5; Bernhard Schnyder/Erwin Murer, Berner Kommentar zum schweizerischen Privatrecht, Band II, Das Familienrecht, 3. Abteilung, Die Vormundschaft, 1. Teilband, Systematischer Teil und Kommentar zu den Art.360-397 ZGB, 2. Lieferung, Kommentar zu den Art.379-397 ZGB, Bern 1984, Art.392 N 97. 
tarafindan açılabileceği kabul edilmektedir ${ }^{236}$. Ancak çocuğun ana babaya karşı korunmasında kanuni temsilci durumundaki ana babanın bizzat davalı taraf olarak ortaya çıkması söz konusu olmaktadır. Böyle bir halde çocuğun hukuki korumadan mahrum bırakılması düşünülemeyeceğine göre, burada yine TMK 426/b.2 hükmü uyarınca çocuğu temsil etmek üzere bir kayyım atanması yönüne gidilmelidir ${ }^{237}$.

Tschümperlin, çocuğun korunması bakımından kişiliği koruyucu davaların, çocuğun korunmasına yönelik önlemlere göre daha avantajlı olduğunu ifade etmektedir ${ }^{238}$. Şöyle ki; kişiliği koruyucu davaların açılabilmesi için ana babanın çocuğun kişiliğini ihlal eden hukuka aykırı bir davranışta bulunması gerekir, burada çocuğun korunmasına yönelik önlemlerden farklı olarak, çocuğun yararının önemli derecede tehlikeye düşmesi şartı aranmamaktadır. Gerçi hakim -çocuğun korunmasına yönelik önlemlerde olduğu gibi- çocuğun kişiliğini koruyucu davalar bakımından da ana babanın takdir yetkisini göz önünde bulunduracaktır. Fakat burada çocuğun yararının önemli derecede tehlikeye düşmesi şartı aranmadığından daha çabuk harekete geçebilmek suretiyle çocuğa daha iyi bir hukuki koruma sağlanmaktadır ${ }^{239}$.

Bununla birlikte kanımızca ana babanın hukuka aykırı davranışıyla çocuğun kişiliğini ihlal ettiği veya ihlal tehlikesine maruz bıraktığı bir çok halde çocuğun yararının da tehlikeye düşeceğini göz önünde bulundurmak gerekir. Zira çocuğun yararı, çocuğun bedensel, zihinsel, ruhsal, ahlaki ve toplumsal gelişimini optimal sağlayacak şartların her halükarda olabildiğince iyi teşekkülünü gerektirir; keza çocuğun yararının gerçekleştirilebilmesi, esasen çocuğun bağımsız bir kişilik olarak idraki ve çocuğun kişiliğine saygı gösterilmesi ile mümkündür. Şu halde çocuğun kişilik değerlerinin ihlali veya ihlal tehlikesine düşürülmesi, çoğu kez çocuğun yararının da ihlali veya ihlal tehlikesine düşmesi sonucunu yaratacaktır. $\mathrm{Bu}$ sebeple çocuğun kişiliğini koruyucu davaların açılabilmesi için gerekli şartların gerçekleştiği yerde çocuğun korunmasına yönelik önlemlere de başvurulabileceği ihtimali dikkate alınmalıdır ${ }^{240}$.

Hakim, TMK 24 hükmü çerçevesinde ana babanın çocuğun kişilik değerlerini ihlal eden veya ihlal tehlikesine düşüren davranışının hukuka aykırılığını değerlendirirken, ana babanın velayeti düzenleyen hükümlerin gereğini yerine getirip getirmediğini ve bu esnada ölçülülük ilkesine riayet edip etmediğini araştırmalıdır ${ }^{241}$. Bu araştırma sonucu ana babanın davranışı

\footnotetext{
${ }^{236}$ BK-Bucher, Art.19 N 230, N 206; krş., BSK ZGB I- Bigler-Eggenberger, Art.19 N 41.

${ }^{237}$ Krş., Tschümperlin, s.112; ayrıca bkz., BK-Hegnauer, aArt.278 N 25, N 26; aArt.279 N 44, fakat krş., N 55.

${ }^{238}$ Tschümperlin, s.111-112.

${ }^{239}$ Tschümperlin, s.112.

${ }^{240}$ Krş., Tschümperlin, s.112-113.

${ }^{241}$ Krş., Tschümperlin, s.316; Serozan, N 249, N 251.
} 
hukuka uygun olarak nitelenemiyorsa, hukuka aykırılık şartı gerçekleşmiş kabul edilmelidir. Bu çerçevede mesela çocuğun eğitiminde uygun olmayan önlemlere başvurulması, özellikle onur kırıcı yaptırımların uygulanması halinde ana babanın hukuka aykırı bir müdahalesi söz konusu olur. Öte yandan çocuğun kişilik değerlerinin ihlalinin zarara yol açması mümkündür. Mesela ana babanın çocuğa kötü muamelede bulunması sonucunda fiziksel veya duygusal kişilik değerlerinin ihlalinden dolayı çocuk, maddi veya manevi zarara uğrayabilir ${ }^{242}$. Keza ana babanın çocuğa karşı velayetten kaynaklanan yükümlerini yerine getirmemesi halinde de mesela çocuğun bakımının veya zorunlu tedavisinin ihmal edilmesi ya da çocuğun eğitiminin engellenmesi sebebiyle çocuğun zarar görmesi söz konusu olabilirr ${ }^{243}$. Çocuğun bu zararının tazmin edilmesi gerekir. Zararın tazmini için ana babanın kusurlu olması $\operatorname{aranır}^{244}$. Burada her türlü kusur, sorumluluk için yeterlidir.

Doktrinde yakın dost ve akraba, özellikle eşler, ana baba ve çocuk arasında istenen manevi tazminat taleplerinde çok dikkatli davranılması gerektiği ifade edilmektedir; buna göre dostluk ve yakın akrabalık manevi tazminatı engellememekle birlikte, tazminat miktarının tespitinde göz önünde tutulur, bunu azaltabilir, hatta bazı hallerde reddini gerektirebilir ${ }^{245}$. Manevi tazminat talebinin somut olayın şartlarına göre değerlendirileceği açıktır; fakat vurgulanmalıdır ki bundan ana baba ile çocuk arasındaki ilişkinin parasal taleplere ve yaptırımlara yer vermeyeceği sonucu çıkarılamaz ${ }^{246}$ (Özellikle maddi ve manevi tazminat talebinden önce, bu talebi doğuran fiilin, çocukla ana baba arasındaki ilişkiyi ağır biçimde zedelemiş olduğu durumlarda).

\section{Sonuç}

Buraya kadarki açıklamalarımız çerçevesinde vardığımız sonuçları şöyle ifade edebiliriz:

Çocuk, doğduğu andan itibaren bağımsız bir kişiliğe sahiptir ve velayet yoluyla çocukla ana baba arasında meydana gelen ilişkide her iki taraf da eşit hak süjesi olarak yer alır. Bu bağlamda çocuğun bağımsız kişiliğe sahip olduğunun ana baba tarafindan idrak edilmesi ve çocuğun kişiliğine sayg1 gösterilmesi gerekir. Esasen çocuk hukukuna ve velayete hakim en üstün ilkeyi oluşturan çocuğun yararının gerçekleştirilmesi ve korunmasının gereği de budur.

\footnotetext{
${ }^{242}$ Krş., BK-Hegnauer, aArt.278 N 25, N 26.

${ }^{243}$ Serozan, N 284.

${ }^{244}$ Eren, s.755, 760.

${ }^{245}$ Eren, s.755; Alfred Keller, Haftpflicht im Privatrecht, Band II, Bern 1987, s. 120.

${ }^{246}$ Serozan, N 251, N 284; İnan, "Çocukların Ana-Babaya Karşı Korunması”, s.25.
} 
Ana babanın her hangi bir surette çocuğun yararını tehlikeye düşürmesi halinde Türk Medeni Kanunu'nun 346 vd. hükümleri uyarınca hakim, çocuğun korunmasına yönelik uygun önlemleri alacaktır.

Bunun dişında Türk Medeni Kanunu'nun 24 ve 25. maddeleri çerçevesinde de çocuğun ana babaya karşı korunması mümkündür. Buna göre ana babanın velayeti düzenleyen hükümlerin gereğini yerine getirmemesi ve/veya ölçülülük ilkesine riayet etmemesi sebebiyle hukuka aykırı olarak nitelenebilecek bir müdahalesi sonucunda çocuğun kişiliğini ihlal etmesi ya da ihlal tehlikesine maruz birakmasi halinde, TMK 25 hükmünde öngörülen savunma talepleri çocuk tarafindan ileri sürülebilir. Çocuğun, kişiliğinin ihlalinden doğan maddi ve manevi tazminat taleplerini de ileri sürebileceği kabul edilmelidir. Burada ayırt etme gücüne sahip çocuk, kişiye sıkı sıkıya bağlı hakkın kullanılması niteliğinde olduğundan savunma ve manevi tazminat taleplerini tek başına ileri sürebilir; buna karşıllk ayırt etme gücü bulunmayan çocuğa söz konusu talepleri ileri sürebilmesi için TMK 426/b.2 hükmü uyarınca bir temsil kayyımının atanması yönüne gidilmelidir. Kișiliğin ihlalinden doğan maddi tazminat talebinin ileri sürülebilmesi için de yine TMK 426/b.2 hükmü uygulanmalıdır. Maddi tazminat talebinin ileri sürülmesi bakımdan varılan bu sonuç, hem ayırt etme gücüne sahip çocuk hem de ayırt etme gücü bulunmayan çocuk için söz konusu olur.

Kişiliği koruyucu davalar ile çocuğun korunması önlemleri karşılaştırıldığında şöyle bir değerlendirme yapmak mümkündür; TMK 24 hükmü çerçevesinde kişiliği koruyucu davaların açılabilmesi için ana babanın çocuğun kişiliğini ihlal eden hukuka aykırı bir davranışta bulunması gerekir, burada çocuğun korunmasına yönelik önlemlerden (TMK 346 vd.) farklı olarak, çocuğun yararının tehlikeye düşmesi şartı aranmamaktadır. Bununla birlikte ana babanın hukuka aykırı davranışıyla çocuğun kişiliğini ihlal ettiği veya ihlal tehlikesine maruz bıraktığ 1 bir çok halde çocuğun yararının da tehlikeye düşeceğini göz önünde bulundurmak gerekir. Şu halde TMK 24 hükmüne göre kişiliği koruyucu davaların açılabilmesi için gerekli şartların oluştuğu bir çok halde TMK 346 vd. uyarınca çocuğun korunmasına yönelik önlemlerin de alınabilmesi şartları gerçekleşmektedir. Ancak hakimin, özellikle kişiliği koruyucu savunma talepleri bakımından, mesela çocuğun kişiliğine yönelik muhtemel saldırının önlenmesine ya da başlamış ve devam etmekte olan saldırının durdurulmasına karar vermesi gereken hallerde, çocuğun korunmasına yönelik önlemlerde olduğu gibi çocuğun yararının tehlikeye düşüp düşmediğini ya da tehlikenin derecesine göre daha ağır önlemlere ihtiyaç olup olmadığını incelemesine gerek yoktur; bundan dolayı hakimin kişiliği koruyucu savunma davaları bakımından daha hızlı hareket imkanının mevcut olduğu söylenebilir. Öte yandan sözü edilen halde çocuğun kişiliğine yönelik hukuka aykırı müdahalenin önlenmesinden veya durdurulmasından sonra TMK $346 \mathrm{vd}$. uyarınca çocuğun korunmasına yönelik önlemlere başvurulmasına da bir engel yoktur. Fakat tabiidir ki bu 
durumda TMK 346 vd. hükümlerinde öngörülen şartların somut olayda gerçekleşip gerçekleşmediği tartışılacaktır.

TMK 24 hükmü çerçevesinde özellikle çocuğun maddi ve manevi tazminat talepleri önem kazanmaktadır. Özellikle ana babanın çocuğa karşı velayetten kaynaklanan yükümlerini yerine getirmeyerek, mesela çocuğun bakımını veya zorunlu tedavisini ihmal etmek ya da eğitimini engellemek suretiyle çocuğun maddi ve manevi varlığını koruma ve geliştirme hakkını ihlal ettiği ve çocuğa zarar verdiği hallerde tazminat talepleri, çocuğun fiziksel ve ruhsal sağaltımında ve hayatını yeniden düzenlemesinde bir imkan ve yardım teşkil edecektir.

Öte yandan TMK 24 hükmünün kişiyi üçüncü kişilerin hukuka aykırı saldırılarından koruyucu defansif niteliği dolayısıyla çocuğun ana babadan kişiliğine saygı gösterilmesi yönünde bazı davranışlarda bulunmasına ilişkin olumlu talepleri, ancak velayeti düzenleyen hükümler çerçevesinde ve TMK 346 vd. uyarınca çocuğu koruyucu önlemler vasitasıyla gerçekleştirilebilecektir. Buna göre mesela çocuğun yeteneklerine ve eğilimlerine uygun düşecek genel ve mesleki bir eğitimin sağlanmasına yönelik talebinin gerçekleştirilmesi, buna ilişkin TMK 340/II hükmüne dayanılarak ve gerekirse çocuğu koruyucu TMK 346 vd. hükümlerine başvurmak suretiyle mümkün olacaktır. 


\section{KISALTMALAR}

aArt. : frühere Fassung des betreffenden Artikels

Abs. : Absatz

Art. : Artikel

b. : bent

BBl : Bundesblatt

BGB : Bürgerliches Gesetzbuch

BK- : Berner Kommentar

BK : Borçlar Kanunu

Bkz. : Bakınız

BSK- : Basler Kommentar

Diss. : Dissertation

dn. : dipnot

Hrsg. : Herausgeber

Krş. : Karşılaştırınız

m. : madde

$\mathrm{N} \quad$ : Nummer

RG. : : Resmi Gazete

$\mathrm{Rz} \quad$ : Randziffer

S. $\quad$ : Say1

S. Sayıs1 : $\quad$ Sira Say1s1

s. : sayfa

SPR : Schweizerisches Privatrecht

TBMM : Türkiye Büyük Millet Meclisi

TMK : Türk Medeni Kanunu

vb. : $\quad$ ve benzerleri

vd. : : ve devam1

ZGB : Schweizerisches Zivilgesetzbuch

ZK- : Zürcher Kommentar

ZSR : Zeitschrift für Schweizerisches Recht 